\title{
DEMOGRAPHIC CHANGE AND ECONOMIC GROWTH IN INDIA
}

\author{
Neha Jain ${ }^{1}$ and Srinivas Goli ${ }^{2,3}$
}

1. Research Scholar at Centre for the Study of Regional Development (CSRD), School of Social Sciences (SSS), Jawaharlal Nehru University (JNU), New Delhi, India

Email: 9ruls4.neha@gmail.com

ORCID: https://orcid.org/0000-0002-8755-9741

2. Australia India Institute, New Generation Network Scholar, The University of Western Australia (UWA)

3. Assistant Professor, Population Studies at Centre for the Study of Regional Development (CSRD), School of Social Sciences (SSS), Jawaharlal Nehru University (JNU), New Delhi India

T: +61 86488 2914, M: +61 41`6271232

Email: srinivas.goli@uwa.edu.au

ORCID: http://orcid.org/0000-0002-8481-484X 


\title{
Demographic Change and Economic Growth in India
}

\begin{abstract}
In this paper, we assess the economic benefits of demographic changes in India by employing econometric models and robustness checks based on panel data gathered over a period of more than three decades. Our analysis highlights four key points. First, the contribution of India's demographic dividend is estimated to be around 1.9 percentage points out of $12 \%$ average annual growth rate in per capita income during 1981-2015. Second, India's demographic window of opportunity began in 2005, significantly improved after 2011, and will continue till 2061. Third, our empirical analysis supports the argument that the realisation of the demographic dividend is conditional on a conducive policy environment with enabling aspects such as quality education, good healthcare, decent employment opportunities, good infrastructure, and gender empowerment. Fourth, the working-age population in India contributes around one-fourth of the inequality in per capita income across states. Thus, to reap the maximum dividends from the available demographic window of opportunity, India needs to work towards enhancing the quality of education and healthcare in addition to providing good infrastructure, gender empowerment, and decent employment opportunities for the growing working-age population.
\end{abstract}

Keywords: Demographic Dividend, Economic Growth, Population Growth, Working-Age Population, Health, Education, Employment

JEL Classification Numbers: J10, J11 


\section{Highlights}

- The contribution of India's demographic dividend is estimated to be around 1.9 percentage points out of $12 \%$ average annual growth rate in per capita income during 1981-2015.

- India's working-age population contributes around $25 \%$ of the inequality in per capita income across states.

- India's demographic window of opportunity began in 2005 and will continue till 2061.

- The realisation of India's demographic dividend is conditional on a conducive policy environment in the country.

- $\quad$ Education and health, employment, infrastructure, and gender empowerment are defining factors for India's demographic dividend. 


\section{Introduction}

Falling fertility rates globally in the last two decades have created massive opportunities for developing countries as they are now in a position to reap the benefits of demographic changes and the consequent shift in age-structural transition. At the country level, India is also completing its fertility transition (reaching the replacement level fertility of 2.1 children per woman) in 2020 (Office of RGI, 2020). India entered a phase that can be aptly termed a 'demographic window of opportunities' in 2005-06 and will likely have a demographic bonus till 2055 . The country is on the cusp of a demographic revolution with the rapidly rising share of the working-age population that was approximately $58 \%$ in 2000 and is estimated to reach a maximum of $65 \%$ in 2036 . Further, India's demographic dividend window is available for a longer period than for any other country because of the huge inter-state variations in the process of demographic transition. Some states in southern and western India will find the closing of their demographic dividend phase in next few years owing to an early decline in fertility levels, while the window of opportunity is yet to commence in high-fertility states such as Bihar, Jharkhand, Madhya Pradesh, Rajasthan, and Uttar Pradesh (UNFPA, 2019).

In 2020, the average age of the Indian population is 29 years, while in other countries such as the USA, Europe, and Japan, it is 40 years, 46 years, and 47 years, respectively (National Policy for Skill Development and Entrepreneurship Report, 2015). India's population-one of the youngest among the large nations of the world-is projected to have a potential growth-inducing impact on the economy (Aiyar \& Mody, 2011; Bloom, 2011; Chandrasekhar, Ghosh, \& Roychowdhury, 2006; James, 2008; Joe, Kumar, \& Rajpal, 2018; Lee \& Mason, 2006; Kumar, 2013; Ladusingh \& Narayana, 2011; Mason, 2005).

Although a few studies have estimated demographic dividend for India in the past (Acharya, 2004; Aiyar \& Mody, 2011; Bloom, 2011; Chandrasekhar et al., 2006; Desai, 2010; Goli \& Pandey, 2010; James, 2008, 2011; James \& Goli, 2016; Joe et al., 2018; Kumar, 2013; Mitra \& Nagarajan, 2005; Navaneetham, 2002; Thakur, 2012), all of them have assessed the database that belong to years before the country reached to 
favourable demographic phase. Considering, the country's present demographic scenario, and population and economic policy interests, there is a strong need for informing the level and pathways for reaping demographic dividend in India. It is in this context, the focus of this paper is to estimate the impact of demographic factors on economic growth in India. The main objective of this paper is to answer the following three questions: (a) What is the estimate of the demographic dividend for India? (b) How far India's capacity to reap demographic dividend is conditional on the policy environment of Indian states such as good health, quality education, decent employment opportunities, and gender empowerment? (c) How much of the inter-state inequality in economic development is explained by their working-age population share across states?

This paper adds to the literature by attempting a robust and comprehensive assessment of demographic change and its economic implications for India through the following four ways: First, it measures the demographic dividend based on the panel dataset of twenty-five states of India for the period 1981-2015 by using conditional Barro regression model under which core policy variables are controlled to estimate a net demographic effect. Secondly, it provides a glimpse of the onset of demographic window of opportunity for the country by systematically examining the influence of the demographic changes on per capita income across different decades 1991-95, 2001-05 and 2011-15. Third, we cautiously check for the interaction of demographic changes with the health, education, employment, and gender empowerment measures to ascertain two aspects: (i) to check whether the positive effects of demographic changes on economic growth are conditioned on the policy environment of the country; (ii) to identify the mechanisms that determine reaping of demographic dividend. Lastly, three robustness checks are performed. First, by comparing our estimates of demographic dividend with other previously existing studies. Secondly, the role of the working-age population in the growing income inequality across Indian states has been checked by using the Regression-Based Inequality Decomposition Model. This model is a significant contribution to the eco-demographic literature which in our knowledge has not been 
attempted by any other study. Third, endogeneity of the working-age share is assessed using an instrumental variable model (two-stage least squares model).

The summary of the findings is as follows: (i) the contribution of the demographic dividend is estimated to be around 1.9 percentage points out of the $12 \%$ average annual growth rate in per capita NSDP during 1981-2015; (ii) India's demographic window of opportunity has begun in 2005 and significantly improving after 2011 and will continue till 2061; (iii) the working-age population explains around one-fourth of the inequality in per capita income across states over time; (iv) better education and health, decent employment opportunities, good infrastructure, and lower gender-bias are defining factors of India's demographic dividend.

The rest of this paper is organised as follows. Section 2 provides a literature review on the demographic dividend. Section 3 discusses stylised facts on India's demographic transition, consequent age-structure change and emergence of windows of opportunity. Section 4 deals with empirical strategy, including the data and descriptive statistics, empirical specifications, and estimation results (both main results and robustness checks). Section 5 deals with the challenges in the way of realising demographic dividend, and Section 6 presents the conclusions.

\section{Literature review}

\subsection{Concept of demographic dividend}

The impact of demographic factors, mainly population size and its growth, on economic development has long been represented by three major contesting views in the literature-the pessimistic theory, the optimistic theory, and the neutralist theory (Birdsall, Kelly, \& Sinding, 2003; Coale \& Hoover, 1958).

However, these growth debates have ignored the effect of changes in age structure on economic performance. It is only after the late 1980 s and particularly the late 1990 s that the significance of age structure and the resulting emergence of 'demographic bonus' was acknowledged in the literature (Bloom 
\& Freeman, 1988; Bloom \& Sachs, 1998; Bloom \& Williamson, 1998; Bloom, Canning \& Sevilla, 2001; Higgins \& Williamson, 1997; Mason, 2001).

The concepts of 'demographic bonus' or 'demographic dividend' emanates when an economy moves from the second stage to the third stage of the demographic transition process in which birth rates begin to fall, coupled with a falling death rate, and leads to a subsequent shift in the age structure of the population towards working-age group (15-59) relative to the population of dependents (0-14 and 60+). Among the dependents, the child population falls dramatically while that of the old-age population grows only moderately, thereby creating opportunities for growth (Bloom, et al., 2003; Bloom, 2011).

The rising share of working-age population creates a potential for many benefits. First, it increases the labour force who produce more than they consume. Second, lower fertility rate induces greater participation of females in the labour market. Third, investment becomes more in health, education and skills of the population as lower resources are needed to be diverted for child caring and rearing. Fourth, household savings increase as working-age people are more capable of saving than the dependents and accord capital for investment purposes. The fifth argument follows from the 'life-cycle hypothesis' which states that people in the working-age save more for their retirement due to improvements in life expectancy (Bloom et al., 2003; Bloom, 2011). However, the realisation of demographic dividend is conditional on existing policy environment such as investments in various sectors (namely, education, skills and health), growing employment opportunities for a rapidly growing young population, flexible labour market, good governance, efficient infrastructure, well developed financial market, family planning, trade openness, efficient fiscal and macro-economic management. Moreover, this dividend is transitory in nature and vanishes over time with further demographic changes (Bloom et al., 2003; Bloom \& Canning, 2003; Bloom, 2011; Lee \& Mason, 2006). 


\subsection{Demographic dividend: the Global context}

The interest in demographic dividend began with the developing countries-especially the Asian countries-as they were having a relatively higher population and started experiencing a fertility decline. The transition occurred first in Japan among all the Asian countries, starting around 1964 and lasting till 2004. Subsequently, the East and Southeast Asian countries began to reap the advantages of demographic dividend. It was estimated that nearly one-third of the economic growth of East Asian countries between 1960 and 2010 could be due to demographic dividend (Bloom \& Williamson, 1998; Bloom, Canning, \& Malaney, 2000; Bloom \& Canning, 2004; Bloom \& Finlay, 2008; Mason, 2001). Similarly, Kelly \& Schmidt (2005) also found that around $20 \%$ of the per capita income growth in a cross country panel of 86 countries over the period 1960-1995 could be attributed to demographic changes, with around $28 \%$ share of Asian countries (including India). A study by Bloom \& Canning (2003) highlighted the significance of the right economic policy framework in realising dividend. For instance, the legalisation of contraception in Ireland resulted in a sharp fall in fertility and led to a rise in the relative share of the working-age population. Besides, favourable policy environment through the promotion of exports and free secondary education along with demographic shift could explain a major part of Ireland's remarkable economic growth of the 1990s, making it the "Irish Tiger".

On the other hand, the slow fertility transition and lack of effective policy environment in Africa could describe the poor economic growth of African countries (Bloom et al., 2003; Bloom and Sachs, 1998; Bloom, Canning, Fink, and Finlay, 2007; Bloom, Canning, Hu et al., 2010). The study by Navaneetham (2002) also found demographic dividend in all Southeast Asian countries except for the Philippines, which suffers from lack of openness to trade and limited human capital formation. Similarly, Latin America could not take advantage of its favourable demographic changes due to a rigid labour market, weak governance and a lack of openness to trade (Bloom, Canning, Evans, et al. 1999). Therefore, changing age structure accompanied by right policy environment are quintessential, otherwise, it may result in rising 
unemployment, higher crime rates and political instability (Bloom and Williamson, 1998; Bloom et al., 2003).

\subsection{Demographic dividend: the Indian context}

Akin to global literature, there are both optimistic and pessimistic views on India's potential of realising the demographic dividend. In the Indian context, studies by Acharya (2004); Chandrasekhar et al. (2006); Desai (2010); Goli \& Pandey (2010); James (2011) and James \& Goli (2016); Mitra \& Nagarajan (2005); Bloom (2011) have theoretically argued that demographic windows of opportunity alone cannot bring about an impetus to growth in the country. The demographic windows of opportunity just creates a supply-side potential and cannot be realised unless the growing working-age population's skills have been enhanced and accommodated in employment.

The studies by Bloom \& Williamson (1998); Bloom \& Canning (2004); Bloom et al., (2007); Bloom \& Finlay (2008); Bloom et al., (2010); Bloom, Finlay, Humair et al., (2015) and Kelly \& Schmidt (2005) have empirically estimated windows of opportunity for a global sample of countries, including India, covering various years from 1960 to the closest year 2005 by taking either a 5- or a 10-year panel. However, these studies have estimated demographic dividend for India before the onset of windows of opportunity for India. Also, these studies have not exploited inter-state differences in the stages of demographic transition in India, thereby providing just an all India average estimate for the demographic dividend.

The study by James (2008) used state-level data for 15 major states in India by constructing a decadal panel for the period 1971-2001. The study found a powerful positive impact of working-age population share on economic growth, despite lacunae in education, health and employment generation, by using the 2SLS method to control for potential possible reverse causality. Another study by Aiyar and Mody (2011) undertook the analysis for the period 1961-2001 for 22 states of India. It found that around 40\%$50 \%$ of the per capita income growth in India since the 1970 s is due to the demographic dividend after 
correcting for inter-state migration and using a two-stage procedure to check for endogeneity issue. But unlike previous studies, this study did not find demographic dividend to be dependent on policy environment. The study by Thakur (2012), however, made a departure from previous studies and found a negative impact of growth in the working-age ratio on economic growth for the period 1981-2011 for 17 major states of India. The study supported its argument on account of the absence of appropriate policies and institutions in the backward states experiencing a major rise in the share of working-age population. Kumar (2013) study found favourable demographic impact for the period 1971-2001 for 17 major states of India but remained sceptical about future growth prospects for India due to the major share of the rise in the working-age population in the economically weaker states which have poor infrastructure and a dearth of proper policies to absorb the growing workforce. More recently, the study by Joe et al. (2018) used state-level panel data from 1980 to 2010 for 15 states of India and found no significant impact of growth in the share of the working-age population on the per capita income growth but could not control for several key policy variables.

Summing up, the empirical estimation of demographic dividend in India suffers from at least three limitations. First, all of the previous studies have analysed demographic dividend before the country reached a favourable demographic phase. In this study, we hypothesis the impact of demographic divided is different at different stages of demographic transition. Thus, the estimation of demographic divided after onset of window of opportunity assumes greater importance. Second, no previous study has empirically checked for the interaction effects of demographic changes with core policy variables to explore the underlying mechanisms leading to demographic dividend and also to estimate the net demographic effect on economic growth of India. Third, also for the first time, this study estimates the contribution of demographic differences to inequality in per capita income across the states. Fourth, the study validates the evidence emerged from the main estimates with multiple robustness checks. 


\section{Demographic transition, age-structure change, and window of opportunity}

An analysis of India's population since 1950 reveals that it has risen tremendously and is estimated to rise further to reach 1.7 billion people by 2060 but after this, a downfall in population size is projected (Fig. 1). The trends in the exponential growth rate of the population at all India level displays an inverted Ushaped pattern with continuously falling population growth rate recorded since 1990-91. The exponential growth rate of the population will become negative for the period after 2060 due to a fall in population size (Fig. 2). This pattern of decreasing exponential growth rate of population is also discernible in all the states of India, except for Tamil Nadu where the growth rate of population is small and the present increase in its population growth is mainly attributed to its inward migration (Fig. 3). Therefore, to comprehend this eccentric pattern of demographic change in India, one has to delve into the underlying forces of fertility and mortality (James, 2011; James \& Goli, 2016).

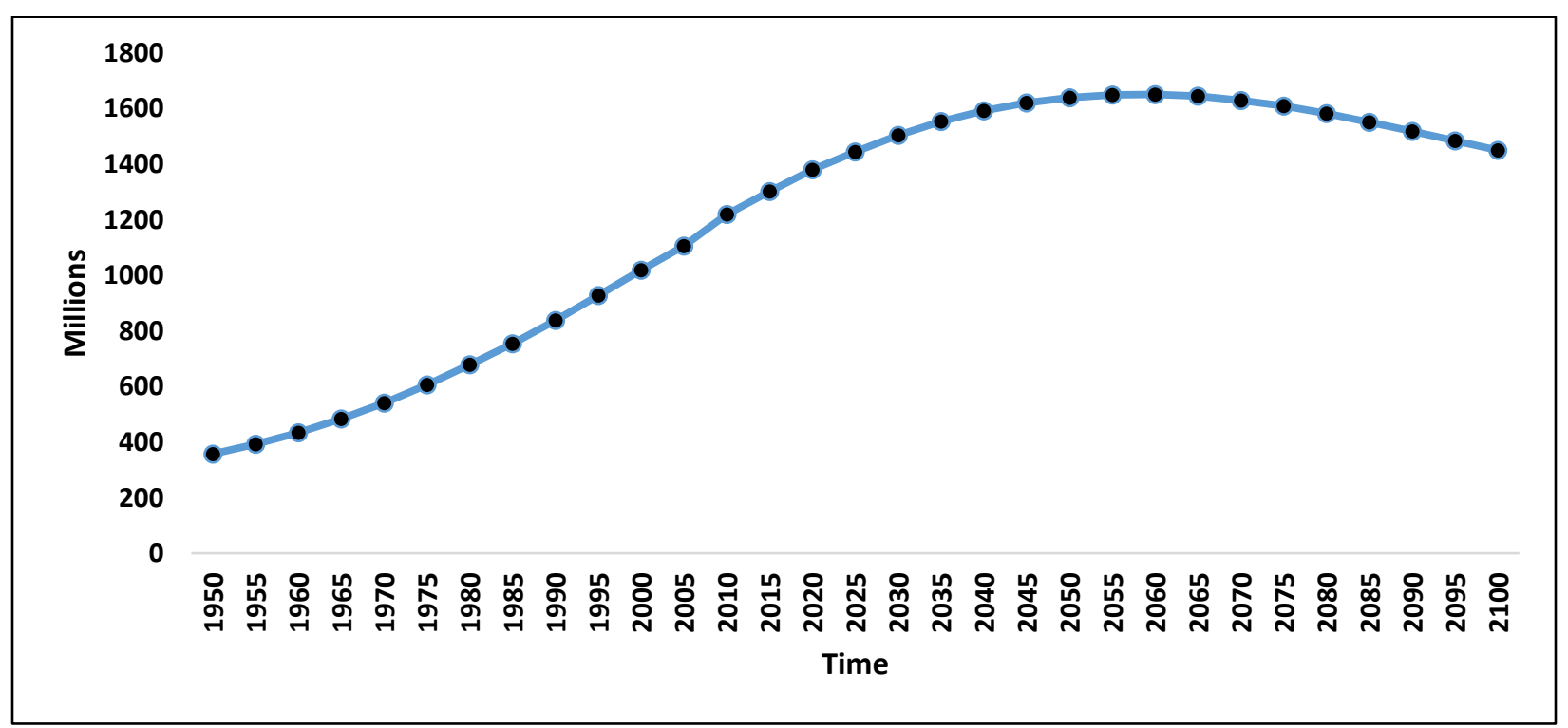

Source: World Population Prospects (19th Revision), United Nations 2019 
Fig. 1. Trends in population size (in millions) in India (1950-2100)

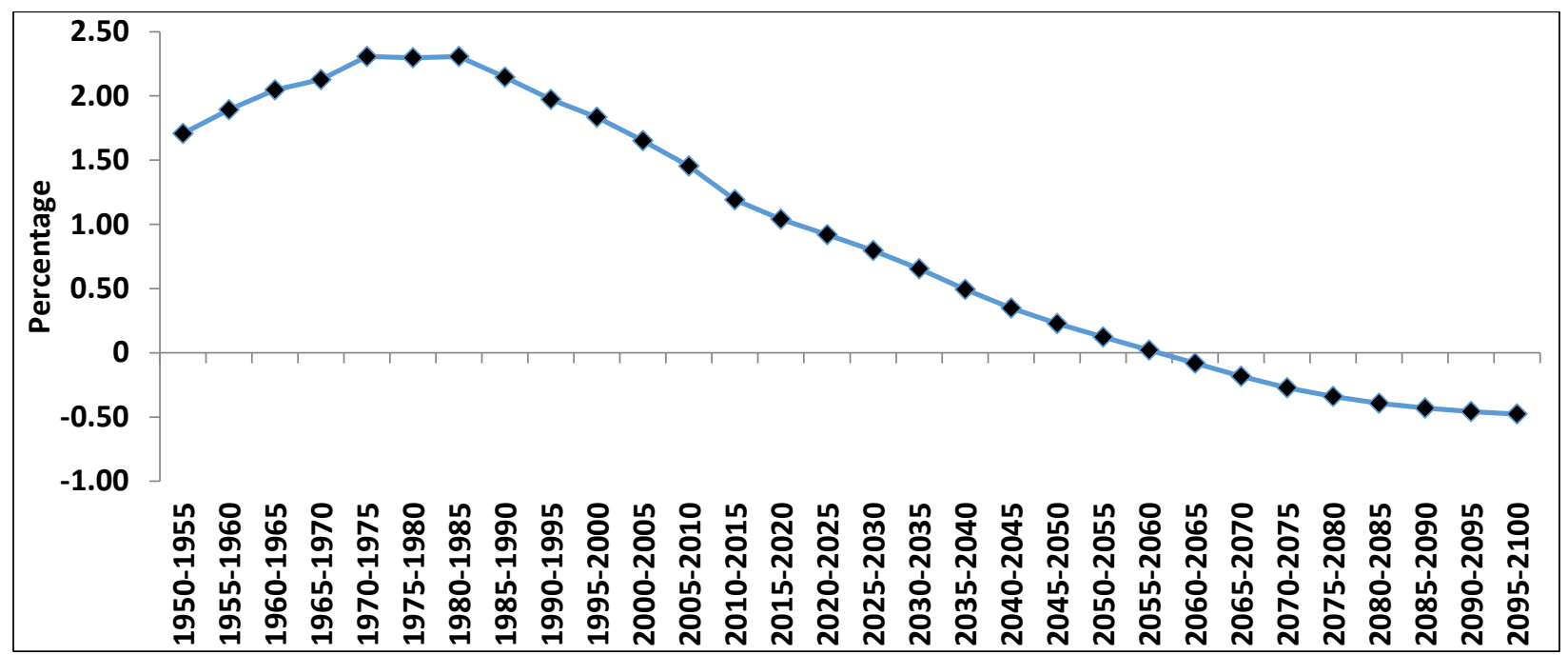

Source: World Population Prospects (19th Revision), United Nations 2019

Fig. 2. Trends in exponential growth rate (in percentage) of population in India

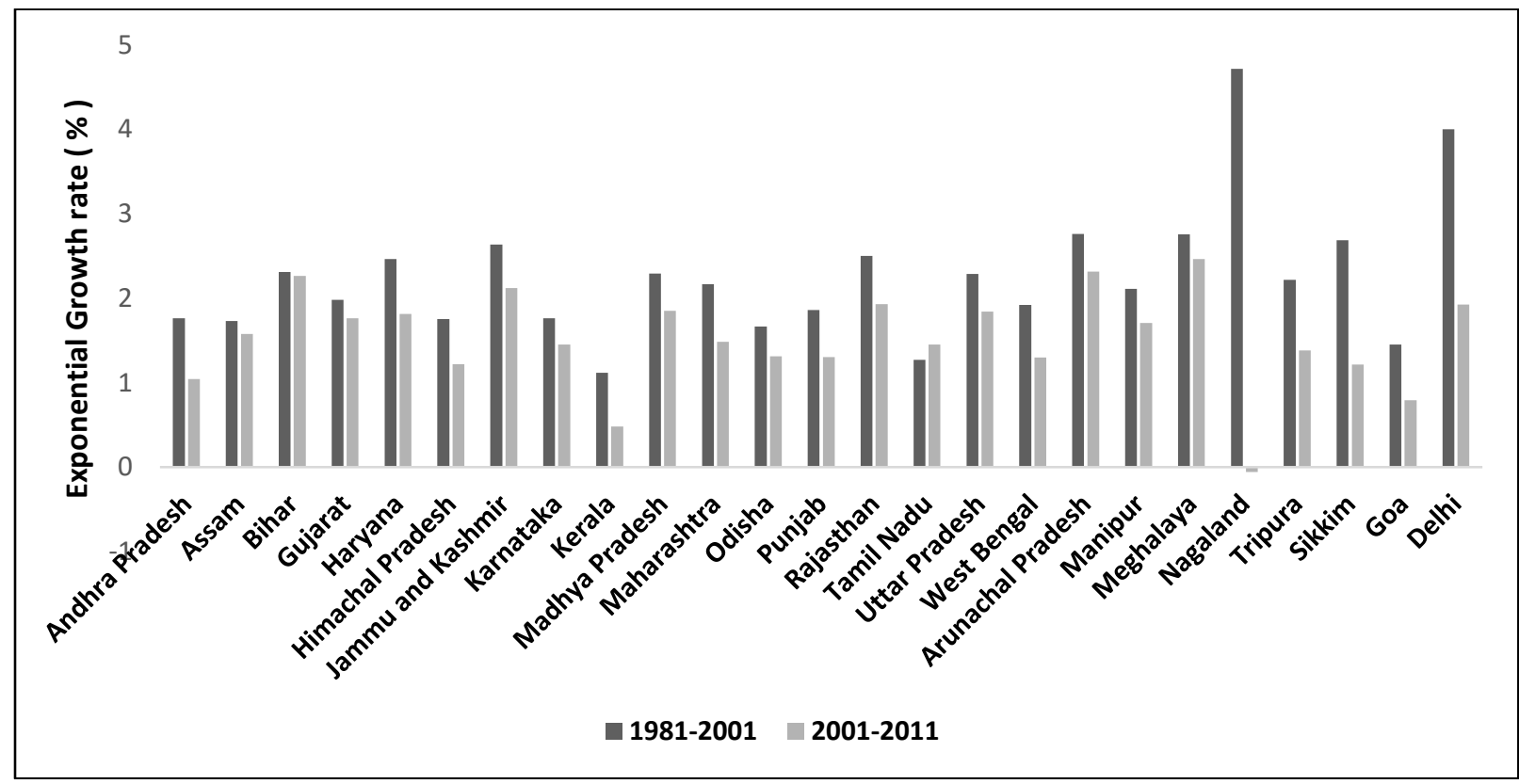

Source: Census of India, Office of the Registrar General of India

Fig. 3. Trends in exponential growth rate (in percentage) across major states of India

The trends in population health parameters such as mortality rate, fertility rate, and life expectancy at birth (Fig. 4) reveal that there is advancement in nation's health, with analogous results at the state level 
too, particularly in demographically laggard states (James \& Goli, 2016). The mortality rate captured by Infant mortality rate (IMR) has gone down from 181 per 1,000 live births in 1950 to 32 per 1,000 live births in 2020, and UN Projections (2019) suggest that it is estimated to reach 5 by the end of this century. The Total Fertility Rate (TFR) has fallen from 5.9 children per woman in 1950 to 2.2 children per woman in 2020, almost touching the replacement level fertility of 2.1 children per woman. According to UN Projections (2019), the TFR will stabilise at 1.7 children per woman after 2050. India's average life expectancy at birth (LEB) has risen from just 37 years in the post-independence period to 70 years in 2020 and is projected to reach 81 years by the end of this century. All these population parameters have important implications for the age structure transition of India's population.

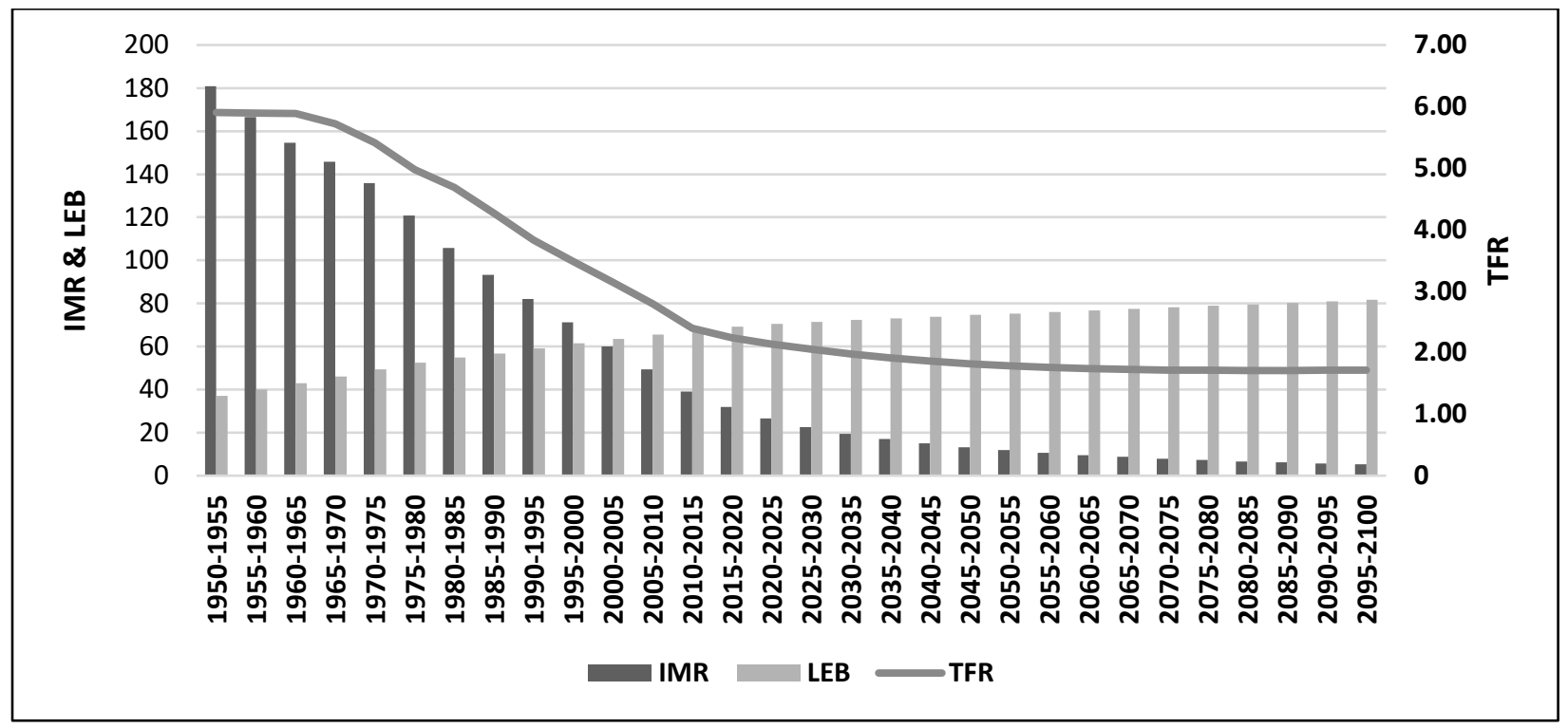

Source: Authors' estimates from various rounds of sample registration system

Fig. 4. Trends in IMR, LEB, and TFR

The age structure transition of the Indian population (1951-2100) reveals (see Fig. 5) that the size of the child population (0-14 years) is continuously falling whereas the share of the older-age population (above 60 years) is rising due to improvement in life expectancy. It is estimated that the percentage of the old- 
age population will go up from $5.7 \%$ in 2000 to $33.2 \%$ in 2100 , surpassing the estimated child population. Even the working-age population will continue to increase till 2035 and experience a downfall thereafter.

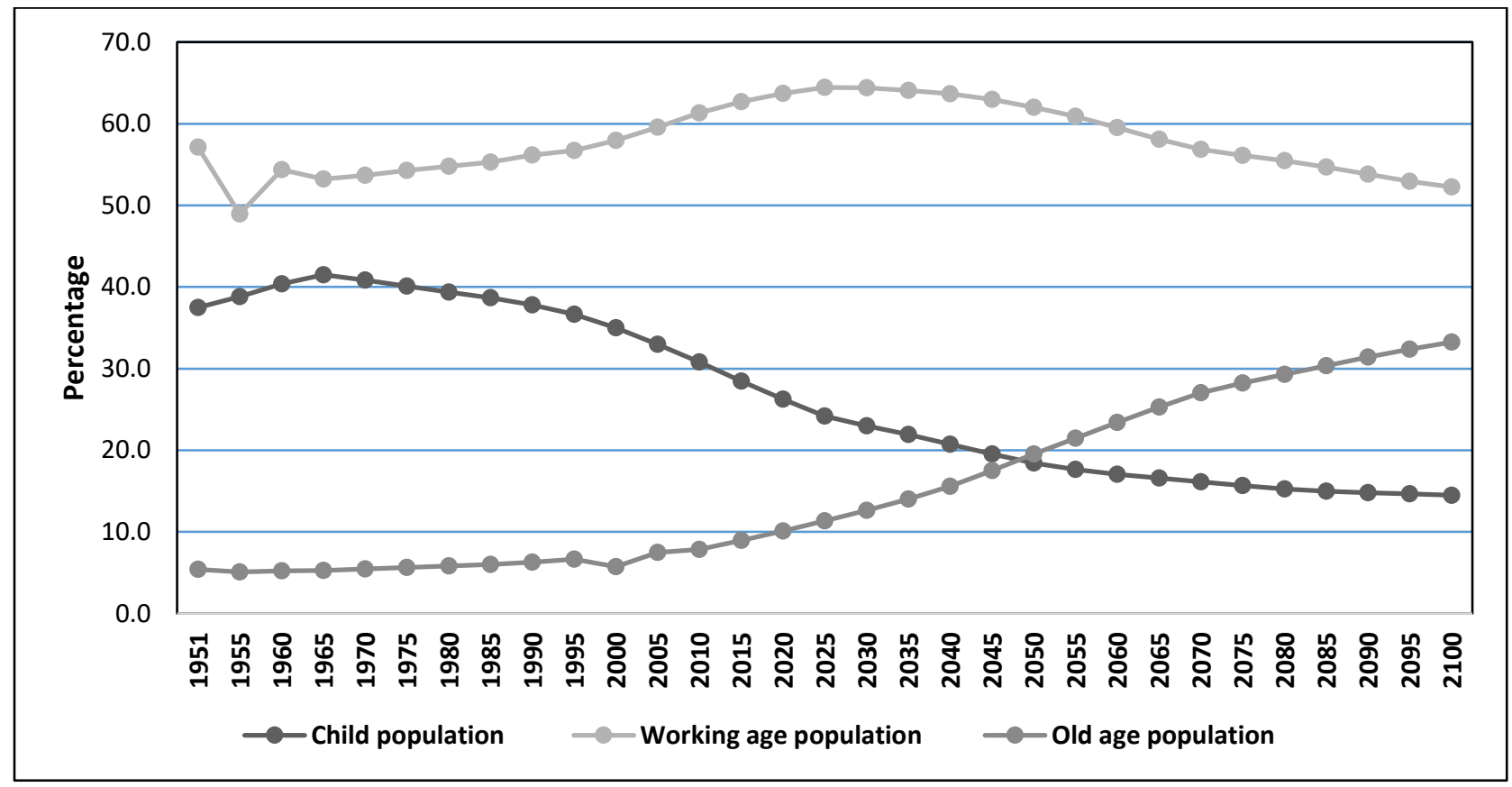

Source: World Population Prospects (19th Revision), United Nations 2019

\section{Fig. 5. Age-Composition of India's population (1951-2100)}

Further, the trends in the share of the working-age population across different states of India (Fig. 6) highlight that the share of the working-age population is rising across all the states of India (except for Meghalaya). But there is heterogeneity in its share with the proportion ranging between $55 \%$ for Bihar to $69.5 \%$ for Manipur in 2011. There is a phenomenal increase in the working-age share in the Manipur (around 19\%) followed by around 10\% rise in the southern states (except Tamil Nadu), Haryana, Himachal Pradesh, Punjab, Tripura, Sikkim, Maharashtra and West Bengal over the last three decades while northern and central Indian states like Bihar, Madhya Pradesh, Rajasthan and Uttar Pradesh have seen a smaller rise in its share. This implies that these states where the fertility rate is still moderately high will have a huge working-age share in the coming years. 


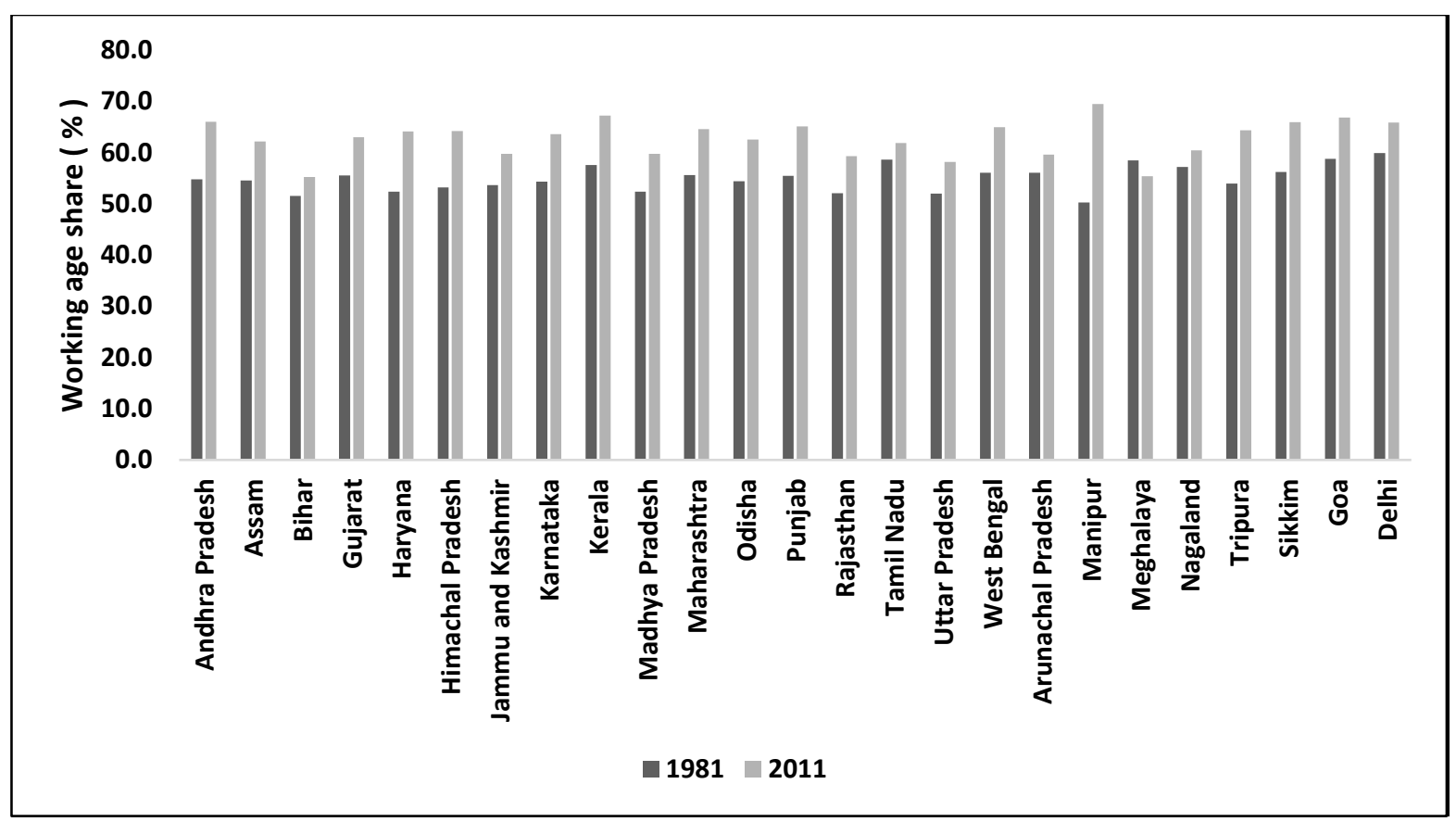

Source: Census of India, Office of the Registrar General India

Fig. 6. Trends in working-age population share across Indian states

\section{$4 \quad$ Empirical strategy}

\subsection{Data and variables description}

This study compiles data from widely acceptable and reliable sources for 25 states of India ${ }^{1}$ for four different periods-1981-85, 1991-95, 2001-05, and 2011-2015. A stacked time-series balanced panel data is constructed for 25 states and 4 time points $\left(25^{*} 4\right)$ having a total of 100 cases. The study variables are grouped into outcome variable, predictor variables, and covariates. The per capita net state domestic product (NSDP) at factor cost (1981 to 2015) obtained from the Central Statistics Organisation (indexed to $2011-12$ constant prices) is the outcome variable. The descriptive statistics presented in Table 1 shows that the average per capita NSDP is Rupees 51,333 with its minimum value ranging from 9,618 to

\footnotetext{
${ }^{1}$ Andhra Pradesh, Assam, Bihar, Gujarat, Haryana, Himachal Pradesh, Jammu and Kashmir, Karnataka, Kerala, Madhya Pradesh, Maharashtra, Odisha, Punjab, Rajasthan, Tamil Nadu, Uttar Pradesh, West Bengal, Delhi, Arunachal Pradesh, Manipur, Meghalaya, Nagaland, Tripura, Sikkim, and Goa
} 
maximum value $2,78,601$, demonstrating glaring disparities in per capita income across states over time. The working-age population ratio (15-59 years), both level and growth, (1981-2011) in percentage terms is considered as the main predictor variable of economic growth taken from the Census of India. It varies from 50.3 to $69.5 \%$ across states over time (1981-2011). Besides, other covariates of economic growth are taken to have a net demographic dividend. These are urbanisation, social sector expenditure, governance index, gender development index, gender empowerment measure, education institutional resources, share of agriculture to non-agriculture, export openness index, infrastructure index, IMR, graduate share and workforce participation rate (see Table 1 for descriptive statistics and data source). A more detailed description of the covariates indicates their rationale of inclusion in the regressions. First of all, the level of urbanisation rate is highly correlated with economic growth as it offers economies of scale, better employment opportunities, good education and health facilities, higher productivity, and induces lower fertility rates and, hence, higher participation of females in the labour market (Bloom et al., 2003; Bloom, Canning, and Fink, 2008; Bloom, 2011). India is also experiencing a fast pace of urbanisation rate, expanding from 28.5\% in 2001 (Census, 2001) to 34\% in the year 2018 (U.N. World Urbanisation Prospects, 2018). Hence, it is an important covariate which no previous study in our knowledge has incorporated so far.

Investments in human capital, in the form of education and health, reflects the quality of labour. It was one of the most essential policy intervention in East Asia which helped in its 'economic miracle' (Bloom et al., 2003; Bloom, 2011). To capture this, we have taken both input and output indicators of human capital. The social sector expenditure by the government on education and health and the availability of education institutional resources reflect input side of human capital formation while infant mortality rate and graduate share indicate health and education status respectively of a nation.

Further, realisation of dividend comes from the removal of gender bias and empowerment of the females, that is, more participation of females in the labour market, in the political sphere, and in the decision 
making, presence of more healthy and educated women, and their control over economic resources (Bloom et al., 2007; Bloom, 2011). To control it, the gender development index and gender empowerment measure are considered.

Next, the quality of institutions reflecting good governance increases a nation's capacity to absorb growing labour force (Bloom \& Williamson, 1998; Bloom et al., 1999; Bloom \& Canning, 2004; Bloom et al., 2007; Bloom \& Finlay, 2008; Bloom et al., 2010; Bloom et al., 2015). To control the quality of institutions, we have taken a state-level governance index.

The share of agriculture to non-agriculture is also controlled as it reflects the structural changes in employment in an economy. A lower share of people engaged in the agriculture sector relative to the nonagriculture sector indicates productivity gain because the agriculture sector has lower productivity as compared to the non-agriculture sector (Bloom et al., 2010).

The availability of efficient physical infrastructures such as roads, rail, power and postal service is essential to capitalise dividend as it will attract new investment and generate additional employment opportunities (Bloom, 2011; Kumar, 2013). Therefore, an infrastructure index is computed to control it. Another important correlate of economic growth is the openness to trade (Bloom \& Williamson, 1998; Bloom et al., 1999; Bloom et al., 2003; Bloom \& Canning, 2004; Bloom et al., 2007; Bloom \& Finlay, 2008; Bloom et al., 2010; Bloom et al., 2015). It is considered by taking the export openness of a state. Lastly, the healthy, educated and large working-age population alone cannot increase economic growth until provided with gainful and decent employment opportunities. Bloom \& Williamson (1998) also suggested to take growth in employment rather than the growth of the working-age population to get a real demographic dividend. Hence, we have included the workforce participation rate to see its direct effects on economic growth. The appendix Table A1 shows the correlation matrix for the pooled sample from 1981 to 2015 . It is evident from the table that the log of working-age share is highly correlated with log per capita income (correlation value is 0.81 ). Other significant correlates of per capita income are gender empowerment 
measure, gender development index, graduate share, IMR, level of urbanisation and share of agriculture to non-agriculture. 
Table 1: Descriptive statistics and source of the variables

\begin{tabular}{|c|c|c|c|c|c|c|}
\hline Variable & Mean & Std. Dev. & Min. & Max. & Data source & Description \\
\hline \multicolumn{7}{|l|}{ Outcome variable } \\
\hline \multirow{3}{*}{$\begin{array}{l}\text { Per capita } \\
\text { income }\end{array}$} & & & & & Central Statistical Organization & Per capita net state domestic product (NSDP) at \\
\hline & & & & & & factor cost (1981 to 2015 ) (indexed to $2011-12$ \\
\hline & \multicolumn{5}{|c|}{ Predictor variable } & \\
\hline & & & & & Cencus of India & \\
\hline ratio & 58.4 & 4.3 & 50.3 & 69.5 & census of inara & $\begin{array}{l}\text { Log of the population aged } 15-59 \text { years as a } \\
\text { percentage of total population }\end{array}$ \\
\hline \multicolumn{7}{|l|}{ Covariates } \\
\hline Urbanisation & 27.5 & 17.2 & 6.6 & 97.5 & Census of India & Proportion of population living in urban areas \\
\hline $\begin{array}{l}\text { Social sector } \\
\text { expenditure }\end{array}$ & 11.7 & 8.0 & 1.6 & 52.8 & $\begin{array}{l}\text { Goswami and Bezbaruah (2011) and RBI } \\
\text { handbook of state statistics }\end{array}$ & $\begin{array}{l}\text { Expenditure on education, healthcare and rural } \\
\text { development by government as a \% of GSDP }\end{array}$ \\
\hline $\begin{array}{l}\text { Governance } \\
\text { index }\end{array}$ & 9.5 & 4.7 & 1.0 & 16.0 & $\begin{array}{l}\text { Basu (2002) and Mundle, Chowdhury, and } \\
\text { Sikdar (2016) }\end{array}$ & Index capturing the quality of institutions \\
\hline $\begin{array}{l}\text { Gender } \\
\text { development } \\
\text { index }\end{array}$ & 0.8 & 0.1 & 0.2 & 0.9 & $\begin{array}{l}\text { Gendering Human Development Indices: } \\
\text { Recasting the Gender Development Index } \\
\text { and Gender Empowerment Measure for } \\
\text { India (2009) }\end{array}$ & $\begin{array}{l}\text { Index measuring gender gap in health, knowledge } \\
\text { and standard of living }\end{array}$ \\
\hline $\begin{array}{l}\text { Gender } \\
\text { empowerment } \\
\text { measure }\end{array}$ & 0.4 & 0.1 & 0.0 & 0.7 & Same as gender development index & $\begin{array}{l}\text { Index capturing economic participation, political } \\
\text { participation and decision making power, and the } \\
\text { power over economic resources }\end{array}$ \\
\hline $\begin{array}{l}\text { Education } \\
\text { institutional } \\
\text { resources }\end{array}$ & 0.2 & 0.2 & 0.0 & 0.8 & $\begin{array}{l}\text { Selected educational statistics, MHRD } \\
\text { 2007, and Department of Higher Education, } \\
\text { MHRD \& DISE, NUEPA (School Education } \\
\text { since 2012-13) }\end{array}$ & $\begin{array}{l}\text { Index measuring availability of education } \\
\text { institutional resources based on the total number } \\
\text { of universities, polytechnics and schools }\end{array}$ \\
\hline $\begin{array}{l}\text { Agriculture/ } \\
\text { non-agriculture }\end{array}$ & 1.5 & 0.9 & 0.0 & 3.8 & NSSO Employment-Unemployment Survey & $\begin{array}{l}\text { Proportion of people employed in agriculture } \\
\text { relative to non-agriculture }\end{array}$ \\
\hline $\begin{array}{l}\text { Export openness } \\
\text { index }\end{array}$ & 0.1 & 0.1 & 0.0 & 0.5 & Dastidar and Veeramani (2014) & $\begin{array}{l}\text { Index measuring export openness in terms of } \\
\text { exports volume }\end{array}$ \\
\hline $\begin{array}{l}\text { Infrastructure } \\
\text { index }\end{array}$ & 0.2 & 0.2 & 0.0 & 0.8 & $\begin{array}{l}\text { Report of Tenth Five Year Plan and RBI } \\
\text { Handbook of State Statistics }\end{array}$ & $\begin{array}{l}\text { Index based on road density, electricity } \\
\text { consumption, rail route length, and number of post } \\
\text { offices }\end{array}$ \\
\hline $\begin{array}{l}\text { Infant mortality } \\
\text { rate }\end{array}$ & 57.7 & 31.3 & 7.0 & 150.0 & Sample registration system & Death of young children under the age of 1 \\
\hline
\end{tabular}


Graduate share

4.1

3.2

Workforce

participation

rate
0.7

19.5
Proportion of graduate and post graduate share out of total population

Workers/population ratio
Census of India

26.7 


\subsection{Empirical specification}

First of all, the decadal impact of the working-age population share on per capita income is assessed by using the simple OLS regression model. Then the pooled OLS regression model based on the combined sample of 100 observations is run to produce an efficient and consistent parameter estimates of the effect of working-age share on per capita income. However, the pooled OLS regression model does not control for variables that are not directly observable or measurable across states like cultural factors or variables that change over time but not across entities. Hence, the panel data regression model is employed to account for these factors. We have modelled F-test for the fixed effect (FE) model, Breusch-Pagan Lagrange Multiplier (LM) test for the random effect (RE) model and Hausman test to decide between FE and RE. The main equation of interest of the panel data regression model used in this paper is given as:

Log per capita $N S D P_{i t}=\alpha+\beta_{0}$ Log working age ratio $_{i t}++\beta_{1}$ Urbanisation $_{i t}$ $+\beta_{2}$ Social sector expenditure $_{i t}+\beta_{3}$ Governance index $_{i t}+$ $\beta_{4}$ Gender development index ${ }_{i t}+\beta_{5}$ Gender empowerment measure $e_{i t}+$ $\beta_{6}$ Education institutional resources $_{i t}+\beta_{7} \frac{\text { Agriculture }_{\text {non-agriculture }}}{i t}+\beta_{8}$ Export openness index $_{i t}$ $+\beta_{9}$ Infrastructure index ${ }_{i t}+\beta_{10} \log$ working age ratio $* \log I M R_{i t} \quad+\beta_{11} \log$ working age ratio $*$

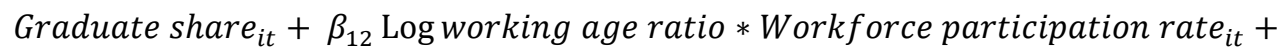
$\beta_{13} \log$ working age ratio $_{i t} *$ time dummy $(1991-95)+\beta_{14} \log$ working age ratio $_{i t} *$ time dummy $(2001-05)+\beta_{15} \log$ working age ratio $_{i t} *$ time dummy $(2011-15)+u_{i}+v_{i t}$ (1)

where $\log$ per capita $N S D P_{i t}$ represents the per capita income of state $i$ in time period $t$. The impact of the main predictor variable Log working age ratio $_{i t}$ is shown both individually and interacted with the health, education, employment, and time dummy factor. $B$ is the coefficient for independent variables. $u_{i}$ $(\mathrm{i}=1 \ldots \mathrm{n})$ is a FE or RE specific to individual state or time period that is not included in the regression. $v_{i t}$ is the error term. 
In the next stage, to get an estimate of demographic dividend for India, the conditional Barro regression model is used. The general equation of Barro conditional regression model is as follows:

$$
\left.g_{y}=\lambda\left(\mathrm{X} \beta+\mathrm{p}+w_{o}-y_{o}\right)+g_{w}\right)
$$

The above equation links growth in income per capita $\left(g_{y}\right)$ to a range of explanatory variable $\mathrm{X}$ that determine steady-state labour productivity, the initial level of income per capita $y_{0}$, and the ratio of working-age to the total population $w_{o}$ and its growth rate $g_{w}$. The constant term captures the participation rate $\mathrm{p}$. The conditional Barro regression model used in this paper is extended to include significant interactions of growth in working-age ratio with health, education, employment, and gender empowerment measure. The statistical expression is given as:

Growth per capita $N S D P_{i t}=\alpha+\beta_{0}$ Log initial working age ratio it $_{1}+\beta_{1} \quad$ Growth working age ratio ${ }_{i t}+$ $\beta_{2}$ Log initial per capita income ${ }_{i t}+\beta_{3}$ Urbanisation $_{i t}+\beta_{4}$ Social sector expenditure $_{i t}+$ $\beta_{5}$ Governance index $_{i t}+\beta_{6}$ Gender development index ${ }_{i t}+$ $\beta_{7}$ Gender empowerment measure ${ }_{i t}+\beta_{8}$ Education institutional resources $_{i t}+\beta_{9} \frac{\text { Agriculture }_{\text {non-agriculture }}}{\text { it }}+$ $\beta_{10}$ Export openness index $_{i t}+\beta_{11}$ Infrastructure index $_{i t}+\beta_{12}$ Log infant mortality rate it + $\beta_{13}$ Graduate share $_{i t}+\beta_{14}$ Workforce prticipation rate $_{i t}+\beta_{15}$ Growth working age ratio $_{\text {it }} *$ $\log I M R_{i t}+\beta_{16}$ Growth working age ratio ${ }_{i t} *$ Graduate share $_{i t}$ $+\beta_{17}$ Growth working age ratio $_{i t} *$ Workforce participation rate it $_{+}+$ $\beta_{18}$ Growth working age ratio $_{i t} *$ Gender empowerment measure $e_{i t}+u_{i t}$

where Growth per capita NSDP it is the annual average growth of per capita net state domestic product in state $i$ for the period 1981 to 2015 . Similarly, Growth working age ratio $i t$ is the growth measured over the period 1981-2015. All control variables are measured at the initial period (1981). Rest of the other explanatory variables have usual interpretations.

While the influence of working-age share on per capita income can be assessed by using an alternative approach of regression-based inequality decomposition model where the relative contribution of 
working-age share in inequality in the per capita income across states overtime is computed. This new method of establishing the importance of working-age share in determining per capita income is presented in the robustness checks at a later stage in the paper.

We further check for potential endogeneity of the working-age share which may arise from the fact that the rise in working-age share just creates a potential labour supply but the actual impact of it on the per capita income works through the channels of education, skills, health, employment, gender development and availability of infrastructure. Hence, we test the robustness of our results adjusted to the endogeneity of working-age share at a later stage in the paper.

\subsection{Estimation results}

\subsubsection{Impact of working-age share on per capita income}

The models (col. 1, 2, 3) of Table 2 provide simple OLS estimates to assess the impact of the log of workingage share on per capita income across three different decades 1991-95, 2001-05, and 2011-15. The working-age share has a significant bearing on per capita income across all time points and the coefficient values are linearly increasing for the successive decades, highlighting the more pronounced effect of demographic changes in recent years. This is in line with UNFPA (2019) which argues that India's demographic window of opportunity has begun in 2005-06.

The R-square of the model also reaches to above $60 \%$ in the last two decades, suggesting that goodness of the fit of models where demographic changes explain a major proportion of variation in per capita income is upright. Moreover, the statistical significance estimate of the working-age share remains stable when all the years are pooled together in col. 4.

\subsubsection{Panel data regression model with other growth correlates}


Further specifications of Table 2 include panel data regression model from equation (1) to control for variables that are not directly observable or measurable across states and the results highlight that the coefficient of the log of working-age share remains statistically significant at $1 \%$ level when all other key policy variables are controlled in models (col. 5, 6, 7). Among covariates, the urbanisation rate emerges to be a significant determinant of per capita income. This is in line with the theoretical argument put forward by Bloom et al. (2003) and Bloom (2011). However, these findings are in contrast to the Bloom et al. (2008) which found no empirical evidence of linkage between the urbanised population share and economic growth. As we said earlier, the relationship between growth correlates and economic growth can change over the time. There is a considerable time-lag between Bloom et al. (2008) and this study. The gender development index and gender empowerment measure also came out to be statistically significant. This implies women's contribution to economic growth need to be sufficiently understood and more policy actions in the areas of education, health and employment need to be enhanced to realise a demographic dividend. Similar policy conclusions are also found in the context of African girls in Bloom et al. (2003), and Indian women in Bloom (2011) and Desai (2010).

In col. 8, however, the coefficient for the log of working-age share loses its statistical significance after including its interaction with key policy variables and time dummy. The results reveal that the interaction of IMR with working-age share is negative and statistically significant which implies that the healthy workforce is essential to reap demographic dividend. The finding is in favour of the hypothesis of Bloom et al. (2003) and Bloom (2011). It has been proved empirically by Bloom \& Williamson (1998); Bloom \& Canning (2004); Bloom et al. (2007); Bloom \& Finlay (2008); Bloom et al. (2015) and Kelly \& Schmidt (2005) which have taken life expectancy as a proxy indicator for health while Joe, et al. (2018) and Thakur (2012) have used IMR to capture the health impact on economic growth.

We have also tried interacting education and working-age share on the lines of Drummond et al. (2014) and Lutz et al. (2019) which found investment in human capital to be an important determinant of 
demographic dividend. Our interaction term of graduate share and working-age share has expected sign but not statistically significant. This statistical insignificance of education term is quite common in growth regressions (see Bloom and Williamson, 1998; Bloom \& Canning, 2004; Bloom \& Finlay, 2008; Bloom et al., 2010 and Bloom et al., 2015). This may be due to measurement errors in the education variable or may indicate poor quality of higher education, lack of skill development and thus low employment prospects in the Indian labour market for all graduates. The Economic Survey (2018-19 and 2019-20) points out lower Gross Enrolment Ratio (GER), poor vocational skills, higher drop-out rates and disparity in a higher education levels across gender and backward social groups, which confirms the latter hypothesis. Further, interacting working-age share with workforce participation rate reveals no significance. This is a new and interesting finding as no study has so far checked empirically for this interaction effect. This may point to the upcoming danger of demographic burden if sufficient employment opportunities are not generated (Bloom et al., 2003 \& Bloom, 2011).

The interaction of the working-age share with three time dummies for the period 1991-95, 2001-05, and 2011-15 are positive, highly statistically significant and their magnitude increasing linearly for successive decades. Finally, in the col. 9 when all the control variables are included (keeping in mind their pairwise correlations), the results are quantitatively stable and the statistical significance of interaction term of IMR with working-age ratio remains unchanged. The interaction with time dummies highlight that India's window of opportunity started after 2005 and its effect got strengthened during 2011-15, again confirming the earlier findings of UNFPA (2019) and James \& Goli (2016). The model explains 83\% of the variations in per capita income, suggesting a goodness of fit of the model. 
Table 2: Impact of working-age population share on per capita income

\begin{tabular}{|c|c|c|c|c|c|c|c|c|c|}
\hline Variable & $\begin{array}{c}(1) \\
\text { OLS } \\
1991-95 \\
\end{array}$ & $\begin{array}{c}(2) \\
\text { OLS } \\
2001-05 \\
\end{array}$ & $\begin{array}{c}\text { (3) } \\
\text { OLS } \\
2011-15 \\
\end{array}$ & $\begin{array}{c}(4) \\
\text { Pooled } \\
\text { OLS }\end{array}$ & $\begin{array}{c}\text { (5) } \\
\text { FE Model }\end{array}$ & $\begin{array}{c}(6) \\
\text { RE Model }\end{array}$ & $\begin{array}{c}\text { (7) } \\
\text { FE Model }\end{array}$ & $\begin{array}{c}\text { (8) } \\
\text { FE Model }\end{array}$ & $\begin{array}{c}\text { (9) } \\
\text { RE Model }\end{array}$ \\
\hline Log working-age ratio & $\begin{array}{c}4.980 * * * \\
(1.607)\end{array}$ & $\begin{array}{c}5.802 * * * \\
(1.131)\end{array}$ & $\begin{array}{c}7.965^{* * *} \\
(1.277)\end{array}$ & $\begin{array}{c}7.797^{* * *} \\
(0.612)\end{array}$ & $\begin{array}{c}3.452 * * * \\
(1.062)\end{array}$ & $\begin{array}{c}4.204^{* * *} \\
(1.231)\end{array}$ & $\begin{array}{c}4.819 * * * \\
(1.318)\end{array}$ & $\begin{array}{c}0.557 \\
(1.020)\end{array}$ & $\begin{array}{c}0.636 \\
(0.940)\end{array}$ \\
\hline Urbanisation & & & & & $\begin{array}{l}0.048^{* * *} \\
(0.00890)\end{array}$ & & $\begin{array}{c}0.0467^{* * *} \\
(0.0111)\end{array}$ & & $\begin{array}{c}0.0188^{* * *} \\
(0.00712)\end{array}$ \\
\hline Social sector expenditure & & & & & $\begin{array}{c}0.00930 \\
(0.00664)\end{array}$ & & & & $\begin{array}{l}0.00738 \\
(0.0134)\end{array}$ \\
\hline Governance index & & & & & $\begin{array}{l}0.00558 \\
(0.0107)\end{array}$ & & $\begin{array}{c}0.0138 \\
(0.0127)\end{array}$ & & \\
\hline Gender development index & & & & & $\begin{array}{c}2.253 * * * \\
(0.709)\end{array}$ & & & & \\
\hline $\begin{array}{l}\text { Gender empowerment } \\
\text { measure }\end{array}$ & & & & & & $\begin{array}{c}2.787 * * * \\
(0.553)\end{array}$ & & & $\begin{array}{l}0.698 \\
(0.748)\end{array}$ \\
\hline $\begin{array}{l}\text { Education institutional } \\
\text { resources }\end{array}$ & & & & & & $\begin{array}{l}0.0867 \\
(0.513)\end{array}$ & $\begin{array}{c}0.171 \\
(0.502)\end{array}$ & & $\begin{array}{c}0.262 \\
(0.261)\end{array}$ \\
\hline Agriculture/non-agriculture & & & & & & $\begin{array}{r}-0.00294 \\
(0.0534)\end{array}$ & & & \\
\hline Export openness index & & & & & & & $\begin{array}{l}0.326 \\
(0.473)\end{array}$ & & \\
\hline Infrastructure index & & & & & & & $\begin{array}{l}0.0314 \\
(0.770)\end{array}$ & & \\
\hline $\begin{array}{l}\text { Log working-age ratio* } \text { Log } \\
\text { infant mortality rate }\end{array}$ & & & & & & & & $\begin{array}{c}-0.0532 * * \\
(0.0219)\end{array}$ & $\begin{array}{l}-0.0401^{*} \\
(0.0244)\end{array}$ \\
\hline $\begin{array}{l}\text { Log working-age } \\
\text { ratio*Graduate share }\end{array}$ & & & & & & & & $\begin{array}{c}0.00602 \\
(0.00585)\end{array}$ & $\begin{array}{c}0.00217 \\
(0.01000)\end{array}$ \\
\hline $\begin{array}{l}\text { Log working-age } \\
\text { ratio*Workforce } \\
\text { participation rate }\end{array}$ & & & & & & & & $\begin{array}{c}0.00148 \\
(0.00162)\end{array}$ & $\begin{array}{c}0.00153 \\
(0.00179)\end{array}$ \\
\hline Log working-age ratio*time & & & & & & & & $0.0549 * * *$ & 0.0339 \\
\hline
\end{tabular}


dummy 1991-95

Log working-age ratio*time

dummy 2001-05

Log working-age ratio*time

dummy 2011-15

Constant

State dummy

Observations

Groups

R-squared

Adjusted R-squared

$\begin{array}{cccc}-9.902 & -13.1^{* * *} & -21.7^{* * *} & -21.2^{* * *} \\ (6.484) & (4.605) & (5.231) & (2.467)\end{array}$

25

25

25

100

25

0.74

$\begin{array}{lll}0.69 & 0.64 & 0.74\end{array}$

0.64

0.43

0.69

$-6.685^{*}$

(3.853)

YES

100

25

0.74

0.73

$-8.060 *$
$(4.754)$

$-10.51 * *$

(5.055)

YES

100

25

0.79

0.78

(0.0191)

$0.125^{* * *}$

(0.0280)

(0.0281)

$0854 *$

$(0.0496)$

(0.0504) (0.0909) 


\subsubsection{Estimating the demographic dividend: Conditional Barro regression model}

Table 3 from equation (2) presents the conditional Barro regression model. The baseline specification in model 1 brings out the large, positive and statistically significant impact of the initial share of working-age population on the per capita income growth. Similar results were found by Thakur (2012). It suggests that states having a larger share of working-age population in 1981, particularly the southern states, West Bengal, Gujarat, Maharashtra, and Punjab (notably these are the leading states in terms of economic growth) have a larger impact on the per capita income growth than those states with a smaller share of working-age population (which coincides with the laggard states such as Bihar, Madhya Pradesh, Rajasthan and Uttar Pradesh). The coefficient of the log initial per capita income is negative and statistically insignificant, suggesting weak convergence. Surprisingly, the growth in working-age ratio is found to have a positive but insignificant impact on per capita income. The study by James (2008) based on OLS specification and Joe et al. (2018) also found similar results. However, these studies have not controlled for key policy variables. Once we control for urbanisation rate, social sector expenditure and governance index in model 2, the coefficient of the growth rate of the working-age population becomes statistically significant. To be precise, an increase of $1 \%$ in the growth rate of the working-age ratio is associated with an increase of $1.9 \%$ in average annual per capita income growth, keeping other factors constant. In other words, the contribution of the demographic dividend is estimated to be around 1.9 percentage points out of the $12 \%$ average annual growth rate in per capita NSDP during 1981-2015. Among covariates, the urbanisation rate also emerges to be a significant determinant of economic growth which is in line with the Bloom et al. (2003) and Bloom (2011).

Models 3 and 4, however, reveal that it is not the growth rate of the working-age ratio but the gender empowerment measures and workforce participation rate that determine economic growth. The studies by Desai (2010); Bloom et al. (2003) \& Bloom (2011) have also argued the same thesis theoretically. To check it further, the growth in working-age ratio is interacted with health, education, employment and 
gender empowerment measures in models 5 and 6 . The results from model 5 highlight the positive and statistically significant impact of the interaction between the growth in working-age share and workforce participation rate on economic growth. This is in line with the argument that demographic changes only increase potential labour supply but their gainful and productive employment is crucial to enhance economic growth (Bloom, 2011). The interaction coefficient is trivial in magnitude reflecting the present status of labour market where half of the workforce is out of the labour market, the widespread presence of less productive informal and contractual jobs and less than a quarter of women being active in the labour market (Economic Survey, 2018-19 and 2019-20). The results from model 6 also bring to notice that demographic dividend could not be reaped automatically without empowering women as shown by the interaction of growth in working-age share with gender empowerment measure. This is one of the most crucial findings of this study which is, for the first time, empirically tested as a part of ecodemographic models. Goodness of fit statistics for the model 6 suggest that the model's explanatory power improve significantly with adjusted R-square reaching $65 \%$. 
Table 3: Estimates of demographic dividend from the conditional Barro convergence regression model

\begin{tabular}{|c|c|c|c|c|c|c|}
\hline Variable & Model 1 & Model 2 & Model 3 & Model 4 & Model 5 & Model 6 \\
\hline \multirow[t]{2}{*}{ Log initial working-age ratio } & $18.57 * * *$ & $17.30 *$ & $12.25^{* * *}$ & $14.86 * *$ & $15.18^{* *}$ & $12.09 * * *$ \\
\hline & $(5.276)$ & $(8.700)$ & $(4.008)$ & (5.920) & $(5.756)$ & $(3.421)$ \\
\hline \multirow[t]{2}{*}{ Growth in working-age ratio } & 1.633 & $1.860^{*}$ & 0.998 & 1.241 & 0.984 & 0.292 \\
\hline & (1.009) & $(1.025)$ & $(0.632)$ & $(1.046)$ & $(0.854)$ & $(0.620)$ \\
\hline \multirow[t]{2}{*}{ Log initial per capita income } & -0.194 & -0.892 & -0.710 & -0.341 & -0.313 & -0.725 \\
\hline & $(0.807)$ & $(0.932)$ & $(0.642)$ & (0.739) & $(0.739)$ & $(0.585)$ \\
\hline \multirow[t]{2}{*}{ Urbanisation } & & $0.0465^{*}$ & & & & \\
\hline & & $(0.0241)$ & & & & \\
\hline \multirow[t]{2}{*}{ Social sector expenditure } & & 0.169 & & & & \\
\hline & & $(0.106)$ & & & & \\
\hline \multirow[t]{2}{*}{ Governance index } & & 0.0191 & & & & \\
\hline & & $(0.0435)$ & & & & \\
\hline \multirow[t]{2}{*}{ Gender empowerment measure } & & & $6.975^{* * *}$ & & & \\
\hline & & & $(2.126)$ & & & \\
\hline \multirow[t]{2}{*}{ Education institutional resources } & & & 0.454 & & & \\
\hline & & & $(0.668)$ & & & \\
\hline \multirow[t]{2}{*}{ Agriculture/non-agriculture } & & 0.411 & & & & \\
\hline & & $(0.456)$ & & & & \\
\hline \multirow[t]{2}{*}{ Export openness index } & & -9.164 & & & & \\
\hline & & (6.673) & & & & \\
\hline \multirow[t]{2}{*}{ Infrastructure index } & & & 0.412 & & & \\
\hline & & & (1.429) & & & \\
\hline \multirow[t]{2}{*}{ Log infant mortality rate } & & & & -0.278 & & \\
\hline & & & & $(0.644)$ & & \\
\hline \multirow[t]{2}{*}{ Graduate share } & & & & 0.0451 & & \\
\hline & & & & $(0.147)$ & & \\
\hline \multirow[t]{2}{*}{ Workforce participation rate } & & & & $0.0587^{*}$ & & \\
\hline & & & & $(0.0302)$ & & \\
\hline Growth in working-age ratio*Log infant & & & & & -0.0643 & \\
\hline mortality rate & & & & & $(0.162)$ & \\
\hline Growth in working-age ratio *Graduate & & & & & 0.0122 & \\
\hline
\end{tabular}


share

Growth in working-age ratio *Workforce

participation rate

Growth in working-age ratio*Gender

empowerment measure

\section{Constant}

Observations

R-squared

Adjusted R-squared

\begin{tabular}{cccccc} 
& & & & $(0.0408)$ \\
& & & $0.0149^{*}$ & \\
& & & & \\
& & & & & \\
& & & & & $1.80782)$ \\
& & & & & $(0.543)$ \\
$-74.65^{* * *}$ & $-66.27^{*}$ & $-44.37^{* *}$ & $-57.63^{* *}$ & $-58.31^{* *}$ & $-40.60^{* * *}$ \\
$(17.37)$ & $(33.93)$ & $(16.18)$ & $(26.89)$ & $(23.86)$ & $(14.21)$ \\
25 & 25 & 25 & 25 & 25 & 25 \\
0.56 & 0.71 & 0.72 & 0.63 & 0.63 & 0.70 \\
0.50 & 0.57 & 0.62 & 0.51 & 0.51 & 0.65 \\
\hline
\end{tabular}

Note: The dependent variable is growth in per capita net state domestic product (1981-2015). Robust standard errors are given in parentheses. ${ }^{* * *} \mathrm{p}<0.01$ $* * p<0.05, * p<0.1$. Population-adjusted weighted regression. All control variables are measured the initial time point (1981). The model does not include gender development index as an explanatory variable because of its high pairwise correlation log initial working-age ratio. 


\subsubsection{Robustness checks}

(i) Comparison of demographic dividend estimate relative to other studies

Comparison of the demographic dividend estimates across the studies is spurious when use different number of samples across the geographies, time frameand also varying methods. However, we used the approach to show (1) a conservative comparison of consistency in the direction of relationship between 'age-structure of population' and 'economic growth' across the studies that used similar models; and (2) also to show the relative significance of the present study. Table 4 gives a summary of findings of studies based on cross country sample as well as those on state-level panel data of India to make a comparison of our results relative to these studies, which are all based on the conditional Barro regression model. Though the studies considered for the comparison do differ in terms of their time frame, sample size and control variables, all of them qualitatively gives a common conclusion that 'age structure of population' is one of the most critical determinants of economic growth, which is consistent with our results. In addition, our study empirically supports the argument put forward by other studies that the effect of working-age population on economic growth depends on 'good' policy environments such as better education and health facilities, decent employment opportunities and gender empowerment (Bloom et al. 2003; Bloom 2011).

However, the studies that focused explicitly on the state-level panel data of India for assessing demographic dividend have rather found a mixed impact of working-age share on economic growth due to following reasons (a) most of them (see James, 2008; Aiyar and Mody, 2011; and Kumar, 2013) have estimated demographic dividend by considering data from the time frame prior to 2001. However, our paper has clearly shown that India's demographic window of opportunity has begun in 2005-06. Thus, there is a less chance to find-out a significant positive association between age-structure and economic growth in studies that used the information prior to the onset of demographic window of opportunity for a country; (b) studies finding a negative or insignificant effect of growth in the working-age share on 
economic growth (see Thakur, 2012 and Joe et al., 2018) have not controlled for key policy factors, thus found unexpected findings; (c) none of them has checked for the interaction effects to find whether the effect of demographic changes is conditioned by the policy framework. Thus, our findings are more robust considering the period in which we have tested the hypothesis with a robust empirical approach and inclusiveness of the wide-range of variables in the models. 
Table 4: Summary of selected studies based on conditional Barro convergence models

\begin{tabular}{|c|c|c|c|c|}
\hline $\begin{array}{l}\text { Studies based on cross- } \\
\text { country panel data }\end{array}$ & Time frame & $\begin{array}{l}\text { Sample } \\
\text { size }\end{array}$ & $\begin{array}{l}\text { Estimator and } \\
\text { specification }\end{array}$ & $\begin{array}{l}\text { Demographic } \\
\text { dividend estimate }\end{array}$ \\
\hline Bloom and Williamson, 1998 & 1965-1990 & 78 & $\begin{array}{c}\text { OLS, Table } 3 \\
\text { spec } 1 \mathrm{~b}\end{array}$ & $1.46(0.34)$ \\
\hline Bloom and Sachs, 1998 & 1965-1990 & 77 & $\begin{array}{l}\text { OLS, Table 6, } \\
\text { spec } 3\end{array}$ & $1.25(0.54)$ \\
\hline $\begin{array}{l}\text { Bloom, Canning, and } \\
\text { Malaney, } 2000\end{array}$ & 1965-1990 & 391 & $\begin{array}{l}\text { OLS, Table } 2, \\
\text { spec } 2\end{array}$ & $1.27(0.38)$ \\
\hline Bloom and Canning, 2003 & 1965-1995 & 507 & OLS, Table 1 & $0.79(0.33)$ \\
\hline Bloom and Canning, 2004 & 1965-1995 & 507 & OLS, Table 1 & $0.99(3.06)$ \\
\hline $\begin{array}{c}\text { Bloom, Canning, Fink, and } \\
\text { Finlay, } 2007\end{array}$ & $1960-2000$ & 610 & $\begin{array}{l}\text { OLS, Table 2, } \\
\text { spec } 1\end{array}$ & $0.80(2.94)$ \\
\hline Bloom and Finlay, 2008 & 1960-2005 & 565 & $\begin{array}{l}\text { OLS, Table 4, } \\
\text { spec } 2\end{array}$ & $1.75(0.27)$ \\
\hline $\begin{array}{l}\text { Bloom, Canning, Hu, Liu, } \\
\text { Mahal, and Yip, } 2010\end{array}$ & $1960-2000$ & 647 & $\begin{array}{l}\text { OLS, Table } 5 \\
\text { spec } 2\end{array}$ & $0.87(0.27)$ \\
\hline $\begin{array}{l}\text { Drummond, Thakoor, and Yu, } \\
2014\end{array}$ & 1960-2010 & 1100 & $\begin{array}{c}\text { FE, Table } 2 \text {, spec } \\
1\end{array}$ & $0.53(3.75)$ \\
\hline Bloom et. al., 2015 & 1965-2005 & 610 & $\begin{array}{c}\text { OLS, Table } 3, \\
\text { spec } 9\end{array}$ & $1.88(0.67)$ \\
\hline $\begin{array}{l}\text { Studies based on Indian state } \\
\text { panel data }\end{array}$ & Time frame & $\begin{array}{l}\text { Sample } \\
\text { size }\end{array}$ & $\begin{array}{l}\text { Estimator and } \\
\text { specification }\end{array}$ & $\begin{array}{l}\text { Demographic } \\
\text { dividend estimate }\end{array}$ \\
\hline \multirow[t]{2}{*}{ James, 2008} & 1971-2001 & 60 & $\begin{array}{l}\text { OLS, Table 4, } \\
\text { spec } 1\end{array}$ & $-0.35(0.86)$ \\
\hline & & & IV Table 4, spec 2 & $24.19(4.19)$ \\
\hline Aiyar and Mody, 2011 & 1961-2001 & 76 & $\begin{array}{l}\text { OLS, Table } 4, \\
\text { spec } 1\end{array}$ & $2.48(1.03)$ \\
\hline Thakur, 2012 & $1981-2011$ & 41 & $\begin{array}{l}\text { OLS, Table 5, } \\
\text { spec } 2\end{array}$ & $-0.02(0.94)$ \\
\hline Kumar, 2013 & $1971-2001$ & 48 & $\begin{array}{l}\text { OLS, Table 2, } \\
\text { spec } 1\end{array}$ & $2.72(1.16)$ \\
\hline Joe et al., 2018 & 1980-2010 & 465 & $\begin{array}{l}\text { OLS, Table 5, } \\
\text { spec } 1\end{array}$ & $0.45(1.57)$ \\
\hline
\end{tabular}

Note: The dependent variable is the average annual growth rate of per capita income. Standard error is reported in parenthesis. 
(ii) Relative contribution of the working-age share in the per capita income inequality: Regressionbased inequality decomposition model

In this method, first, an income-generating function is set as

$\ln \left(y_{i}\right)=\alpha+\sum_{i=1}^{k} \beta_{i} x_{i}+\varepsilon$

where $y_{i}$ is per capita income for $i=1, \ldots ., k, x_{i}$ is a vector of explanatory variable. $\beta_{i}$ are the corresponding regression coefficients that are estimated by OLS regression and $\varepsilon$ is the residual term, assumed to be unrelated to other variables.

$\ln \left(y_{i}\right)=\alpha+\sum_{i=1}^{k} Z_{i}+\varepsilon$

where each $Z_{i}$ for $i=1, \ldots ., k$, is a 'composite' variable, equal to the product of an estimated regression coefficient and an explanatory variable. To calculate inequality decomposition, the value of $\alpha$ is not relevant as it is constant for every observation. Thus, one may consider the following equation

$\ln \widehat{\left(y_{l}\right)}=\alpha+\sum_{i=1}^{k} Z_{i}$

where dependent variable is $y_{i}$ hat or predicted income variable. Note, there is no residual term and we can neglect the constant term $\alpha$.

Then following Shorrocks (1982), Fields \& Yoo (2000) and, Fields (2003), the contribution of each composite variable to total per capita income inequality can be assessed as follows:

$\sigma^{2}(\mathrm{y})=\sum_{i=1}^{k} \beta_{i} \operatorname{cov}\left(\mathrm{y}, x_{i}\right)+\sigma^{2}(\varepsilon)$

where, $\sigma^{2}(y)$ is the variance of $y, \operatorname{cov}\left(y, x_{i}\right)$ represents the covariance of $y$ with each variable $\left(x_{i}\right)$ and this term can be considered as the relative contribution of the factor components to total per capita income inequality which sums up to $100 \%$.

Appendix Table A2 reports three different models of pooled OLS regression from equation (3) based on the correlation among the explanatory variables. Table 5 from equation (4) reveals that around one-fourth of the income inequality is contributed by the working-age share across states, after controlling other core policy variables, reassuring the significance of the working-age population in determining per capita 
income. Other important variables significantly contributing to inequality is the graduate share, gender empowerment measure, gender development index, urbanisation rate, export openness index, log infant mortality rate, governance index, and workforce participation rate. 
Table 5: Estimates of regression-based inequality decomposition model-Contribution of variation in working-age population share to inequality in per capita NSDP

\begin{tabular}{lccc}
\hline Variable & Model 1 & Model 2 & Model 3 \\
\hline Log working-age ratio & $27.63^{* * *}$ & $25.39^{* * *}$ & $17.81^{* * *}$ \\
Urbanisation & $19.53^{* * *}$ & $13.81^{* * *}$ & \\
Social sector expenditure & $3.99^{* *}$ & $3.66^{*}$ & 0.96 \\
Governance index & & $8.54^{* * *}$ & $9.66^{* * *}$ \\
Gender development index & $16.09 * * *$ & & \\
Gender empowerment measure & & $30.98^{* * *}$ & \\
Education institutional resources & 0.17 & 0.29 & \\
Agriculture/non-agriculture & & 1.79 & \\
Export openness index & $18.95^{* * *}$ & & $0.28^{* * *}$ \\
Infrastructure index & & 2.03 & $12.04^{* *}$ \\
Log infant mortality rate & & & $32.27^{* * *}$ \\
Graduate share & & & $8.19^{* * *}$ \\
Workforce participation rate & & 13.47 & 9.94 \\
Residual & 13.64 & 100 & 100 \\
Total & 100 & & \\
\hline
\end{tabular}

Note: The dependent variable is log per capita net state domestic product. Standard errors are given in parentheses. ${ }^{* * *} \mathrm{p}<0.01,{ }^{* *} \mathrm{p}<0.05,{ }^{*} \mathrm{p}<0.1$. Population-adjusted weighted regression. The pooled OLS regression of decomposition model is given in Appendix Table A2. 
(iii) Checking endogeneity of the working-age share: Instrumental variable model

As discussed previously in the empirical specification section, the working-age share may be an endogenous variable (Bloom \& Williamson, 1998; Bloom \& Canning, 2003; Bloom \& Canning, 2004; Bloom et al., 2010; Bloom, 2011; Drummond, et al., 2014). Its endogeneity is assessed by instrumenting it with gender development index, workforce participation rate, graduate share and infrastructure index. The instruments selected are in line with the theoretical argument that the impact of working-age share on per capita income should work through the channels of education, employment, health, lower gender bias and availability of infrastructure (Bloom et al., 2003; Bloom, 2011). The statistical expression for the model is as follows:

Log per capita $N S D P_{i t}=\alpha+\beta_{0}\left(\right.$ Log working age ratio ${ }_{i t}=$ Gender development index $x_{i t}$, Workforce participation rate ${ }_{i t}$, Graduate share ${ }_{i t}$, Infrastructure index $\left.x_{i t}\right)+\beta_{i}$ Control variables $_{i t}+u_{i t}$.

where $\log$ per capita $N S D P_{i t}$ is the dependent variable. Log working age ratio ${ }_{i t}$ is the instrumented variable. Other explanatory variables have usual interpretation.

The 2SLS estimates from equation (5) presented in Table 6 suggest the statistical significant bearing of working-age share on per capita income when instrumented by gender development index, workforce participation rate, graduate share and infrastructure index, controlling for other variables, time dummy and state dummy. A $1 \%$ rise in the working-age share leads to a rise in per capita income by $5.8 \%$ in col.3. The working-age share is an endogenous variable as, under the endogeneity test, the null hypothesis of the exogeneity of the working-age share is rejected at a conventional level of significance. The instruments used are valid as per the test of over-identifying restrictions and the value of F-statistic shows that instruments are not weekly correlated with the endogenous regressors. 
Table 6: Estimates from instrumental variables model (2SLS)

\begin{tabular}{|c|c|c|c|}
\hline Variable & Model 1 & Model 2 & Model 3 \\
\hline Log working-age ratio & $\begin{array}{c}3.037 * * * \\
(1.133)\end{array}$ & $\begin{array}{c}5.962 * * * \\
(1.475)\end{array}$ & $\begin{array}{c}5.803 * * * \\
(1.786)\end{array}$ \\
\hline Urbanisation & $\begin{array}{l}0.0175^{* *} \\
(0.00785)\end{array}$ & & \\
\hline Social sector expenditure & $\begin{array}{c}-0.0284 * * * \\
(0.00985)\end{array}$ & & \\
\hline Governance index & & $\begin{array}{c}-0.0215^{* * *} \\
(0.00681)\end{array}$ & \\
\hline Education institutional resources & & $\begin{array}{l}0.0476 \\
(0.270)\end{array}$ & \\
\hline \multirow[t]{2}{*}{ Agriculture/non-agriculture } & & & $0.113^{*}$ \\
\hline & & & $(0.0682)$ \\
\hline Export openness index & & $\begin{array}{c}0.242 \\
(0.263)\end{array}$ & $\begin{array}{l}0.744^{*} \\
(0.407)\end{array}$ \\
\hline Log infant mortality rate & & $\begin{array}{c}-0.383^{*} \\
(0.227)\end{array}$ & $\begin{array}{c}-0.448 * \\
(0.254)\end{array}$ \\
\hline Time dummy & YES & YES & YES \\
\hline State dummy & YES & YES & YES \\
\hline Constant & $\begin{array}{l}-2.449 \\
(4.490)\end{array}$ & $\begin{array}{c}-12.18 * * \\
(5.638)\end{array}$ & $\begin{array}{c}-11.57^{*} \\
(6.858)\end{array}$ \\
\hline Observations & 100 & 100 & 100 \\
\hline Groups & 25 & 25 & 25 \\
\hline First-stage F statistic & 10.61 & 11.66 & 12.38 \\
\hline \multicolumn{4}{|c|}{ Over-identifying restrictions (Ho: zero correlation between instruments and the error term) } \\
\hline Sargan chi2 & $3.21455(p=0.3597)$ & $6.35509(p=0.0956)$ & $8.09886(p=0.0540)$ \\
\hline \multicolumn{4}{|c|}{ Exogeneity of instrumented explanatory variable (Ho: Variable is exogenous) } \\
\hline Robust score & $7.11173(p=0.0077)$ & $18.2902(p=0.0000)$ & $11.0987(p=0.0009)$ \\
\hline Robust regression & $4.56755(p=0.0362)$ & $14.126(p=0.0004)$ & $9.07023(p=0.0037)$ \\
\hline
\end{tabular}

Note: The dependent variable is log per capita net state domestic product. Robust standard errors are given in parentheses. ${ }^{* * *} p<0.01,{ }^{* *} p<0.05,{ }^{*} p<0.1$. Population-adjusted weighted regression. 


\section{$5 \quad$ Challenges in the way of realising demographic dividend}

The empirical analysis highlights the importance of education, health, employment, lower gender bias, high level of urbanisation and several other crucial policy factors in determining demographic dividend for India. However, several lacunae in these areas act as a hindrance in India's way of realising the demographic dividend. These shortcomings have been identified with the help of our empirical findings, which are again corroborated by findings of previous studies.

First and foremost is the abysmal level of public investments in social infrastructure (James, 2008; 2011; Oxfam India Report, 2018). The total expenditure on health as a percentage of GDP is less than $2 \%$ while the global average is around 6\%. Despite a tremendous improvement in health indicators, the healthadjusted life expectancy (HALE) at birth in India is only 59.3 years as per WHO (2016) estimate. On the education front, though there is remarkable progress in India's Gross Enrolment Ratio in the primary and secondary level, it is significantly lower in higher education (26.3\% in 2018-19 as per MHRD provisional data, cited in economic Survey 2018-19). Also, there is a disparity in higher education levels across gender and backward social groups. The literacy rate has touched 77\% mark in 2017-18 (PLFS Annual report 201718), but the learning outcomes are still miserable. The Annual Status of Education Report (2018) highlights that 1 out of 4 children leaving class 8 lack basic reading skills. The quality of the workforce depicted by its skill profile is also gloomy. As per the PLFS Annual Report (2017-18), only $2.26 \%$ of the people in the productive age group (15-59 years) received formal vocational training.

Second, as per the PLFS Annual Report (2017-18), around half of the working-age population in India is out of the labour market. Further, there is a worsening of the quality of employment due to the growing informalisation and casualisation of jobs. One cannot ignore the other half of the demographic dividend that is the status of women in the sphere of education, health and labour market. The female LFPR in India 
is one of the lowest in the world and less than a quarter of them were active in the labour market in 201718. [see CPC 2006; Desai 2010]

Another constraint is the negative trend in household savings rate which is a principal source of capital accumulation and an important parameter of demographic dividend (Economic Survey, 2018-19). Besides this, according to Oxfam India Report (2018), India has the highest disparity among all the nations of the world on all the parameters of income, wealth and consumption. This rising income disparity may further dampen the consumption levels in the future, thereby affecting the demand in the market. Lastly, the level of urbanisation in India is around 34\% in 2018 but there is a vast interstate disparity (U.N. World Urbanisation Prospects, 2018). This rapid pace of urbanisation due to non-availability of adequate and quality non-farm employment in rural areas has put excessive population pressure in cities leading unhealthy living environment, greater pollution levels and disease burden (Bloom et al., 2010; Bloom, 2011; James \& Goli, 2016).

The next upcoming issue emerging from the age structure transition of the population is the rapidly growing old-age dependency ratio with a greater disease and disabilities in the future (Economic Survey, 2018-19). According to Goli \& Pandey's (2010) estimates based on UN projections, there will be only a $2 \%$ increase in the working-age population in the 2005-2050 period, whereas the size of the older population will increase by $13 \%$ during the same period. Moreover, in India, the older population doubles in only 25 years, which is in stark contrast to the US where it takes around 70 years for this doubling (James \& Goli, 2016). Thus, India will prematurely develop into ageing societies which will have serious economic and health burdens unless it acts against it (see Japan's case study in Bloom, Canning, \& Sevilla, 2003). There is a possibility of the 'Second Demographic Dividend' for the country (Ladusingh \& Narayana, 2011), but it hinges on the healthy and financially literate older population, with adequate availability of developed financial markets, income and social security measures, which at present seems to be an arduous task in India (Bloom, 2011; James \& Goli, 2016; Goli, Reddy A, James \& Srinivasan, 2019). Therefore, India should 
start preparing for this future challenge; otherwise it may get old before getting rich, despite the observed demographic bonus.

\section{Conclusions}

India's demographic window of opportunity began in 2005, while the demographic dividend effect got strengthened in 2011-15 and the country will continue to have demographic bonus until 2061 . The demographic dividend is estimated to be about 1.9 percentage points per annum for the period 19812015 based on the panel of 25 states of India, after controlling core policy variables. The relative proportion contribution of working-age population is estimated to be around one-fourth of the income inequality across states over time, reassuring its significance in determining per capita income. However, empirical estimation based on the interaction effects and instrumental variable model reveals that healthy workforce, productive employment, higher education level, better infrastructure and empowerment of women is quintessential for better realisation of the demographic dividend of India. Further extending this logic and also based on the insights from the literature, we put forward some of the major lacunae in reaping the desired benefits of demographic change as dwindling spending on education and health sector, poor quality of learning, skill mismatches, the presence of chronic illnesses and disabilities, falling employment rates, gender disparities (in education, health, labour market and overall sex ratio), child marriage, falling household savings rate, urbanisation of rural poverty and rapidly rising ageing population (Bloom, 2011; James \& Goli, 2016; Goli, Reddy A, James \& Srinivasan, 2019). Besides, given the fact that there exist huge inter-state variations in socio-economic and demographic profiles, the realisation of demographic dividend is conditional on the performance of northern states where the window of opportunity has just begun and these states typically underperform in growth correlates compared to other Indian states (Oxfam India Report, 2018; Economic Survey, 2018-19). Therefore, prompt policy action is needed to prevent demographic window of opportunity turning into a demographic nightmare. 


\section{Acknowledgements}

An earlier version of this paper was presented at the 3rd International Conference on Business, Economics and Sustainable Development (ICBESD 2020), held at the National Institute of Securities Markets (NISM), Mumbai (March 2-3, 2020), eventually winning the best paper award. We have greatly benefitted from the valuable comments by the conference participants and take this opportunity to express our gratitude for it. We would also like to thank Mr K. S. James, Director of International Institute for Population Sciences (IIPS), and Mr P. M. Kulkarni, former Professor at the Centre for Study in Regional Development (CSRD), Jawaharlal Nehru University (JNU), New Delhi, for a number of fruitful discussions on the demographic profile of India.

\section{Declaration of Conflict of Interest: None}

This research did not receive any specific grant from funding agencies in the public, commercial, or notfor-profit sectors.

\section{References}

Acharya, S. (2004). India's Growth Prospects Revisited. Economic and Political Weekly, 39(41), $\quad$ 15151538

Aiyar, S. \& Modi, A. (2011). The Demographic Dividend: Evidence from Indian States. IMF Working Paper 11/38. Retrieved from https://www.imf.org/external/pubs/ft/wp/2011/wp1138.pdf.

Birdsall, N., Kelley, A. C., \& Sinding, S. (2003). Population Matters: Demographic Change, Economic Growth, and Poverty in the Developing World. Oxford Scholarship Online. ISBN13: 9780199244072 . DOI:10.1093/0199244073.001.0001

Bloom, D.E. \& Freeman, R.B. (1988). Economic development and the timing and components of population growth. Journal of Policy Modeling, 10(1), 57-81.

Bloom, D.E. \& Sachs, J.D. (1998). Geography, demography, and economic growth in Africa, In Brainard, W.C. and Perry, G.L. (Eds.), Brookings Papers on Economic Activity, 2, 207- 
Bloom, D. E. \& Williamson, J. G. (1998). Demographic Transitions and Economic Miracles in Emerging Asia. World Bank Economic Review, 12(3), 419-56.

Bloom, D. E., Canning, D., Evans, D. K., Graham, B. S., Lynch, P., \& Murphy. E. E. (1999). Population Change and Human Development in Latin America, background paper for IPES 2000, Harvard Institute for International Development.

Bloom, D. E., Canning, D., \& Malaney, P., (2000). Population dynamics and economic growth in Asia. Population and Development Review, 26, 257-290.

Bloom, D.E., Canning, D., \& Sevilla, J. (2001). Economic growth and the demographic transition, NBER Working Papers 8714, National Bureau of Economic Research, Inc.

Bloom, D. E., \& Canning, D. (2003). Contraception and the Celtic Tiger. The Economic and Social Review, 34, 229-247.

Bloom, D. E., Canning, D. \& Sevilla, J. (2003). The demographic dividend: A new perspective on the economic consequences of population change. Santa Monica, CA: Rand.

Bloom, D. E. \& Canning, D. (2004). Global Demographic Change: Dimensions and Economic Significance. NBER Working Paper 10817, NBER.

Bloom, D. E. \& Finlay, J. E. (2008). Demographic Change and Economic Growth in Asia. Program on the Global Demography of Aging Working Paper 41, PGDA Retrieved from: http://www.hsph.harvard.edu/pgda/working.htm

Bloom, D. E., Canning, D. and Fink, G. (2008). Urbanisation and the Wealth of Nations. Program on the Global Demography of Aging Working Paper 30. Retrieved from: http://www.hsph.harvard.edu/pgda/working.htm

Bloom, D. E., Canning, D., Hu, L., Liu, Y., Mahal, A., \& Yip, W. (2010). The Contribution of Population Health and Demographic Change to Economic Growth in China and India. J Comp Econ, 38(1), 1733. doi:10.1016/j.jce.2009.11.002.

Bloom, D. E. (2011). Population Dynamics in India and Implications for Economic Growth. PGDA Working Paper No.65. Retrieved from http://www.hsph.harvard.edu/program-on-the-global-demography-ofaging/WorkingPapers/2011/PGDA_WP_65.pdf.

Bloom, D. E., Finlay, J., Humair, S., Mason, A., Olaniyan, O., \& Soyibo, A. (2015). Prospects $\quad$ for Economic Growth in Nigeria: A Demographic Perspective. Program on the Global Demography of Aging at Harvard University, Working Paper No. 127. Retrieved from: https://cdn1.sph.harvard.edu/wpcontent/uploads/sites/1288/2012/11/PGDA_WP_127_Bloom-et-al.pdf

Cashin, P. \& Sahay, R. (1996). Internal Migration, Center-State Grants and Economic Growth in the States of India. IMF Staff Papers, 43(1).

Census. (1981, 1991, 2001, 2011). Office of Registrar General, Ministry of Home Affairs, Government of India.

Chandrasekhar, C.P., Ghosh, J., \& Roychwdhury, A. (2006). The Demographic Dividend and Y Young India's Economic Future. Economic and Political Weekly, 41(49), 5055-5064.

Coale, Ashley J. \& Hoover, E. (1958). Population growth and Economic Development in Low Income Countries - A Case Study of India's Prospects. Princeton: Princeton University Press.

Dastidar \& Veeramani. (2014). Does trade openness affect manufacturing growth at the Indian state level? MPRA Paper No. 58876, posted 26. September 2014 15:29 UTC. Retrieved from: http://mpra.ub.uni-muenchen.de/58876/

Datta, P. (1985). Inter State Migration in India. Margin, 18(1), 69-82.

Desai, S. (2010). The Other Half of the Demographic Dividend. Economic \& Political Weekly, 14(40), $12-14$. 
Dobbs, R., Manyikaet, J., \& Woetzel, J. (2015). The Power of Parity: Advancing Women's Equality in India. McKinsey Global Institute.

Drummond, P., Thakoor, V., \& Yu, S. (2014). Africa Rising: Harnessing the Demographic Dividend. IMF Working papers 14/143. Retrieved from: https://www.imf.org/external/pubs/ft/wp/2014/wp14143.pdf

Fields, G., \& Yoo, G. (2000). Falling labour income inequality in Korea's economic growth: patterns and underlying causes. Review of Income Wealth, 46(2), 139-159.

Fields, G. (2003). Accounting for Income Inequality and Its Change: A New Method, with Application to the Distribution of Earnings in the United States. Research in Labor Economics.

Goli, S. \& Pandey, A. (2010). Is India 'getting older before getting rich'? Beyond demographic assessment. Research Gate, Retrieved from: https://www.researchgate.net/publication/234040176

Goli, S., Reddy A, B., James, K. S., Srinivasan, V., (2019). Economic Independence and Social Security among India's Elderly. Economic and Political Weekly, 39, 32-41.

Goswami, B. \& Bezbaruah, M. P. (2011). Social Sector Expenditures and Their Impact on Human Development: The Indian Experience. Indian Journal of Human Development, 5(2).

Higgins, M. \& Williamson, J.G. (1997). Age structure dynamics in Asia and dependence of foreign capital. Population and Development Review, 23(2), 261-293.

James, K. S. (2008). Glorifying Malthus: Current Debate on 'Demographic Dividend' in India. Economic \& Political Weekly, 43(25), 63-69.

(2011). India's Demographic Change: Opportunities and Challenge. Science, 333， 576,

DOI: $10.1126 /$ science.1207969

James, K. S. \& Goli, S. (2016). Demographic Changes in India: Is the Country Prepared for the Challenge. Brown Journal of World Affairs, 23(1), 169-187.

Joe, W., Kumar, A., \& Rajpal, S. (2018). Swimming against the tide: economic growth and demographic dividend in India. Asian Population Studies, DOI: 10.1080/17441730.2018.1446379

Kelly, A.C. \& Schmidt, R.M. (2005). Evolution of Recent Economic-Demographic Modeling: A Synthesis. Journal of Population Economics, 18(2) (Jun., 2005), 275-300.

Kumar, U. (2013). India's Demographic Transition: Boon or Bane? Asia and the Pacific Policy Studies, 1(1), 186-203.

Ladusingh, L. \& Narayana, M. R. (2011). Demographic Dividends for India: Evidence and Implications

Based on National Transfer Accounts. ADB Economics Working Paper Series 292.

Lee, R. \& Mason, A. (2006). Back to Basics: What is the Demographic Dividend. Finance \& Development, 43(3), 16-17.

Lutz, W., Cuaresma, J. C., Kebede, E., Prskawetz A., Sanderson, W. C., \& Striessniga, E. (2019).

Education rather than age structure brings demographic dividend. PNAS, 116/26. Retrieved from: https://www.pnas.org/content/pnas/116/26/12798.full.pdf

Mason, A. (2001). Population Change and Economic Development in East Asia: Challenges Met, Opportunities Seized. Stanford, Stanford University Press.

Mason, A. (2005). Demographic Transition and Demographic Dividends in Developed and Developing Countries. United Nations Expert Group Meeting on Social and Economic Implications of Changing Population Age Structure, Mexico City, August 31-September

Ministry of Skill Development \& Entrepreneurship, Government of India. (2015). National Policy for Skill Development and Entrepreneurship Report. Retrieved from: Http://Pibphoto.Nic.In/Documents/Rlink/2015/Jul/P201571503.Pdf

Ministry of Finance, Government of India. (2019). Economic Survey 2018-

19. Retrieved from: https://www.indiabudget.gov.in/economicsurvey/ 
Ministry of Statistics and Programme Implementation, Government of India. (2019). Periodic Labour Force Survey (PLFS) Annual Report (2017 -2018). Retrieved from: http://mospi.nic.in/sites/default/files/publication_reports/Annual\%20Report\%2C\%20PLF S\%202017-18_31052019.pdf?download=1

Ministry of Women and Child Development, Government of India. (2009). Gendering Human Development Indices: Recasting the Gender Development Index and Gender Empowerment Measure for India. Retrieved from: https://www.undp.org/content/dam/india/docs/gendering_human_development_indices_s ummary_report.pdf.

Ministry of Human Resource Development, Department of Higher Education, Government of India. (2007). Selected educational statistics. Retrieved from: http://14.139.60.153/bitstream/123456789/483/3/SAnalysisSelected\%20Educational\%20 Statistics\%202004-05.pdf

Mitra, S. \& Nagarajan, R. (2005). Making Use of the Window of Demographic Opportunity: an Economic Perspective. Economic and Political Weekly, 40(50), 5327-32.

Mundle, S., Chowdhury, S. \& Sikdar, S. (2016). Governance Performance of Indian States 2001- 02 and 2011-12. National Institute of Public Finance and Policy. Working paper No. $164 . \quad$ Retrievd from: http://nipfp.org.in/publications/working-papers/ Navaneetham, K. (2002). Age Structural Transition and Economic Growth: Evidence from South and Southeast Asia. Centre for Development Studies Working Paper No 337, Retrieved from: http://unpan1.un.org/intradoc/groups/public/documents/apcity/unpan012698.pdf

Oxfam India Report. (2018). Mind the Gap - The State of Employment in India. Retrieved from: https://www.oxfamindia.org/sites/default/files/2019-03/Full\%20Report\%20-\%20LowRes\%20Version\%20\%28Single\%20Pages\%29.pdf

Reserve Bank of India. (2018). Handbook of Statistics on Indian States. Retrieved from: https://rbidocs.rbi.org.in/rdocs/Publications/PDFs/OHANDBOOK201819_FDF254115C6 094E3CAB32A1DCDA9ADA88.PDF

Shorrocks, A. F. (1982). Inequality decomposition by factor components. Econometrica, 50(1), 211.

Skeldon, R. (1986). Migration Pattern in India during the 1970s. Population and Development Review, 12(4), 759-780

Thakur, V. (2012). The Demographic Dividend in India: Gift or curse? A State level analysis on differing age structure and its implications for India's economic growth prospects. International development, London School of Economics and Political Science, Working Paper-

No.12-128.

Thompson, W. S. (1929). Population. American Journal of Sociology, 34(6), 959-975.

United Nations, World Population Prospects: The 2019 Revision. Department of Economic and Social Affairs, Population Division, New York.

United Nations, World Urbanization Prospects: The 2019 Revision. Department of Economic and Social Affairs, Population Division, New York. Retrieved from: https://population.un.org/wup/Publications/Files/WUP2018-Report.pdf

UNFPA (2019). Demographic Dividend Opportunity in India: Evidence and Policy Imperatives. Unpublished document. 


\section{APPENDIX}

\section{Table A1: Correlation matrix}

\begin{tabular}{|c|c|c|c|c|c|c|c|c|c|c|c|c|c|c|}
\hline & $\begin{array}{l}\text { Log } \\
\text { PCY }\end{array}$ & $\begin{array}{l}\text { Log } \\
\text { WAR }\end{array}$ & Urban & SSE & $\begin{array}{l}\text { Governa } \\
\text { nce }\end{array}$ & GDI & GEM & EIR & $\begin{array}{l}\text { Agriculture/n } \\
\text { on-agriculture }\end{array}$ & EOI & Infra & IMR & Grad & WPR \\
\hline Log PCY & 1.00 & & & & & & & & & & & & & \\
\hline Log WAR & 0.81 & 1.00 & & & & & & & & & & & & \\
\hline Urban & 0.57 & 0.49 & 1.00 & & & & & & & & & & & \\
\hline SSE & 0.19 & 0.19 & -0.32 & 1.00 & & & & & & & & & & \\
\hline Governance & 0.01 & 0.01 & 0.13 & 0.12 & 1.00 & & & & & & & & & \\
\hline GDI & 0.59 & 0.60 & 0.19 & 0.33 & -0.21 & 1.00 & & & & & & & & \\
\hline GEM & 0.78 & 0.67 & 0.47 & 0.02 & 0.06 & 0.40 & 1.00 & & & & & & & \\
\hline EIR & $0.14^{-}$ & -0.11 & 0.08 & -0.41 & 0.02 & -0.37 & 0.19 & 1.00 & & & & & & \\
\hline Agri/non-agri & $\begin{array}{r}- \\
0.54 \\
\end{array}$ & -0.65 & -0.56 & 0.02 & -0.05 & -0.43 & -0.44 & 0.09 & 1.00 & & & & & \\
\hline EOI & 0.45 & 0.41 & 0.07 & 0.13 & 0.00 & 0.24 & 0.34 & -0.08 & -0.28 & 1.00 & & & & \\
\hline Infra & 0.27 & 0.20 & 0.71 & -0.57 & 0.06 & -0.20 & 0.43 & 0.55 & -0.35 & 0.04 & 1.00 & & & \\
\hline IMR & 0.63 & -0.67 & -0.35 & -0.33 & -0.14 & -0.62 & -0.41 & 0.39 & 0.47 & -0.25 & 0.11 & 1.00 & & \\
\hline Grad & 0.74 & 0.68 & 0.82 & -0.02 & 0.20 & 0.33 & 0.58 & -0.10 & -0.60 & 0.33 & 0.47 & -0.55 & 1.00 & \\
\hline WPR & 0.32 & 0.34 & -0.06 & 0.46 & -0.17 & 0.43 & 0.16 & 0.00 & 0.03 & 0.25 & -0.24 & -0.22 & 0.12 & 1.00 \\
\hline
\end{tabular}

Note: PCY stands for per capita income; WAR, working-age ratio; SSE, social sector expenditure; GDI, gender development index; GEM, gender empowerment measure; EIR, education institutional resources; EOI, export openness index; Infra, infrastructure; IMR, infant mortality rate; Grad, graduate share; and WPR, workforce participation rate. 
Table A2: Pooled OLS regression-based decomposition of inequality in per capita income

\begin{tabular}{|c|c|c|c|}
\hline Variable & $\begin{array}{c}(1) \\
\text { Model } 1\end{array}$ & $\begin{array}{c}(2) \\
\text { Model } 2\end{array}$ & $\begin{array}{c}\text { (3) } \\
\text { Model } 3\end{array}$ \\
\hline Log working-age ratio & $\begin{array}{c}2.892 * * * \\
(0.720)\end{array}$ & $\begin{array}{c}2.658 * * * \\
(0.823)\end{array}$ & $\begin{array}{c}1.865^{* * *} \\
(0.649)\end{array}$ \\
\hline Urbanisation & $\begin{array}{c}0.0159 * * * \\
(0.00322)\end{array}$ & $\begin{array}{c}0.0113 * * * \\
(0.00368)\end{array}$ & \\
\hline Social sector expenditure & $\begin{array}{l}0.0181^{* *} \\
(0.00746)\end{array}$ & $\begin{array}{c}0.0166^{*} \\
(0.00862)\end{array}$ & $\begin{array}{c}0.00436 \\
(0.00647)\end{array}$ \\
\hline Governance index & & $\begin{array}{c}-0.0239 * * * \\
(0.00673)\end{array}$ & $\begin{array}{c}-0.0271^{* * *} \\
(0.00576)\end{array}$ \\
\hline Gender development index & $\begin{array}{c}1.071^{* * *} \\
(0.308)\end{array}$ & & \\
\hline Gender empowerment measure & & $\begin{array}{c}2.183 * * * \\
(0.453)\end{array}$ & \\
\hline Education institutional resources & $\begin{array}{r}-0.0537 \\
(0.126)\end{array}$ & $\begin{array}{r}-0.0992 \\
(0.158)\end{array}$ & \\
\hline Agriculture/non-agriculture & & $\begin{array}{c}-0.0226 \\
(0.0596)\end{array}$ & \\
\hline Export openness index & $\begin{array}{c}2.436^{* * *} \\
(0.386)\end{array}$ & & $\begin{array}{c}1.065^{* * *} \\
(0.378)\end{array}$ \\
\hline Infrastructure index & & $\begin{array}{c}0.363 \\
(0.385)\end{array}$ & $\begin{array}{c}0.151 \\
(0.289)\end{array}$ \\
\hline Log infant mortality rate & & & $\begin{array}{c}-0.191 * * \\
(0.0778)\end{array}$ \\
\hline Graduate share & & & $\begin{array}{c}0.108 * * * \\
(0.0191)\end{array}$ \\
\hline Workforce participation rate & & & $\begin{array}{r}0.0157^{* * *} \\
(0.00499)\end{array}$ \\
\hline Constant & $\begin{array}{l}-2.935 \\
(2.724)\end{array}$ & $\begin{array}{c}-1.554 \\
(3.300)\end{array}$ & $\begin{array}{c}2.728 \\
(2.722)\end{array}$ \\
\hline Observations & 100 & 100 & 100 \\
\hline R-squared & 0.86 & 0.86 & 0.90 \\
\hline
\end{tabular}

Note: The dependent variable is log per capita net state domestic product. Standard errors are given in parentheses. ${ }^{* * *} p<0.01,{ }^{* *} p<0.05,{ }^{*} p<0.1$. Population-adjusted weighted regression. 